\title{
FY99 Final Report for the Expedited Technology Demonstration Project: Demonstration Test Results for the MSO/off-gas and Salt Recycle System
}

\author{
Peter C. Hsu
}

Martyn G. Adamson

May 1999

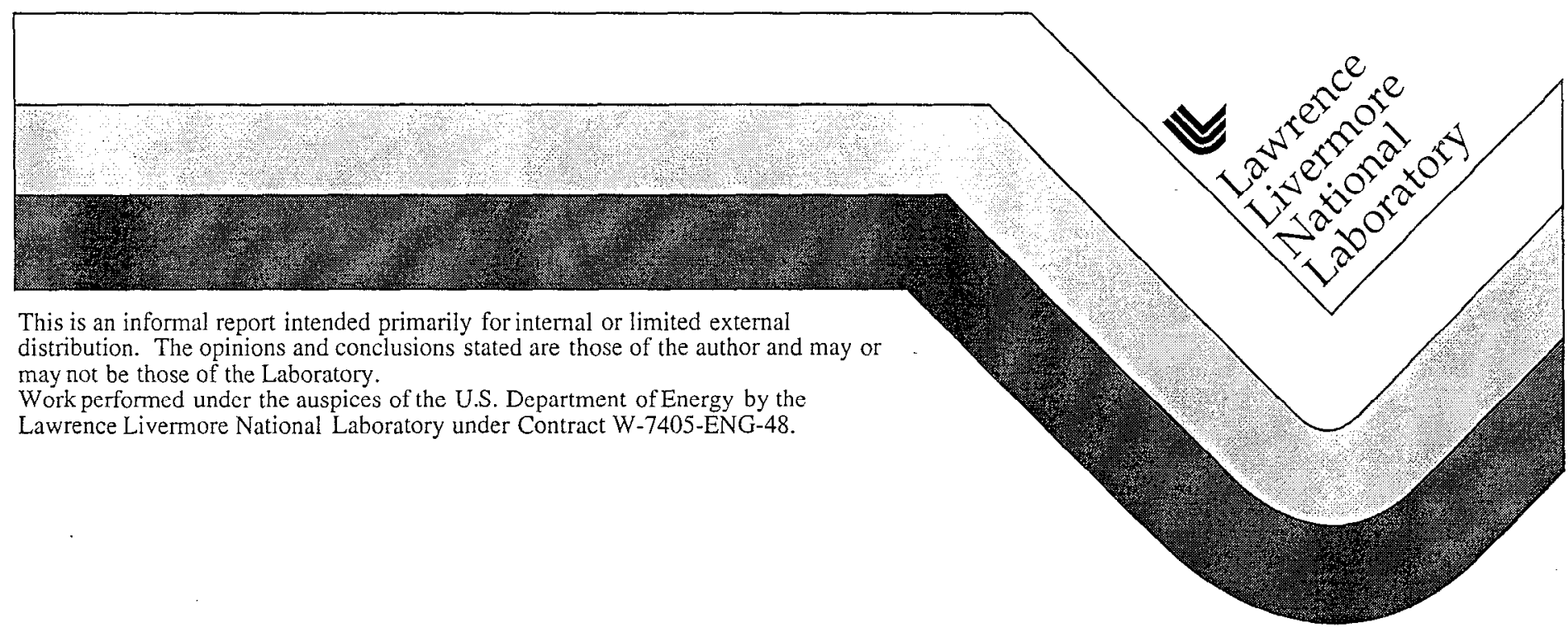




\section{DISCLAIMER}

This document was prepared as an account of work sponsored by an agency of the United States Government. Neither the United States Government nor the University of California nor any of their employees, makes any warranty, express or implied, or assumes any legal liability or responsibility for the accuracy, completeness, or usefulness of any information, apparatus, product, or process disclosed, or represents that its use would not infringe privately owned rights. Reference herein to any specific commercial product, process, or service by trade name, trademark, manufacturer, or otherwise, does not necessarily constitute or imply its endorsement, recommendation, or favoring by the United States Government or the University of California. The views and opinions of authors expressed herein do not necessarily state or reflect those of the United States Government or the University of California, and shall not be used for advertising or product endorsement purposes.

This report has been reproduced directly from the best available copy.

Available to DOE and DOE contractors from the Office of Scientific and Technical Information

P.O. Box 62, Oak Ridge, TN 37831

Prices available from (615) 576-8401, FTS 626-8401

Available to the public from the

National Technical Information Service

U.S. Department of Commerce

5285 Port Royal Rd.,

Springfield, VA 22161 


\section{FY99 Final Report for the Expedited Technology Demonstration Project: Demonstration Test Results for the MSO/off-gas and Salt Recycle System}

Peter C. Hsu and Martyn G. Adamson

Lawrence Livermore National Laboratory

Expedited Technology Demonstration Project

Earth \& Environmental Science Directorate

Livermore, CA 94550

Prepared for: U. S. Department of Energy

Oakland Operations Office

Waste Management Division

May 1999 


\section{Contents}

\section{Page}

FIGURES

TABLES 4

EXECUTIVE SUMMARY 5

1. Introduction 7

2. Process Description $\quad 7$

3. System Description 8

4. Experiments in the MSO/Off-Gas System Results 8

5. Experiments in the Salt Recycle System and Results 24

6. MSO Vessel Wall Thickness 25

7. Conclusion 31

Acknowledgments $\quad 32$

References $\quad 32$

Appendix 1

Appendix 1b 35 


\section{Figures}

1. Integrated MSO System

2. The Resin Slurry Feed System

3. Off Gas Data for Ion Exchange/Mineral Oil Slurry Feed

4. Flowsheet for Aqueous Processing of Spent Salt 
Tables

1. Operational Schedule of the MSO Facility in FY99

2. Resin Slurry Demonstration

3. Off-gas Composition

4. Real Test Specimens for MSO Treatability Study in FY98

5. Run Conditions for MSO Demo with RTS\#3

6. Off-gas Composition for the MSO Demo with RTS\#3

7. Concentration of POHCs in the Off-Gas for the Treatability with the RTS\#3 Specimen

8. Run Conditions for MSO Demo with RTS\#4

9. Off-gas Composition for the MSO Demo with RTS\#4

10. Concentration of POHCs in the Off-Gas for the Treatability with the RTS\#4 Specimen

11. Composition of Activated Carbon for the MSO Demonstration

12. Residue analysis of salt taken from the MSO vessel

13. Residue analysis of salt taken from off-gas components

14. Off-gas analyzer readings

15. Off-gas analyzer readings from the run of particulate carbon at $35 \mathrm{~g} / \mathrm{min}$

16. Run Conditions for MSO Demo with TNT-loaded Carbon

17. Off-gas Composition for the MSO Demo with TNT-loaded Carbon

18. Concentration of POHCs in the Off-Gas for the TNT-Loaded Activate Carbon Demonstration

19. Run Conditions for MSO Demo with Carbon Slurry

20. Off-gas Composition for the MSO Demo with Carbon Slurry Feed

21. Salt Recycle System Analytical Work for SR7

22. Salt Recycle System Analytical Work for SR8

23. Salt Recycle System Analytical Work for SR9

24. Cation Compositions of SR7, SR8, SR9 Before and After Salt Recycle (Dry Basis)

25. MSO Vessel Inspection Results 


\section{EXECUTIVE SUMMARY}

Molten Salt Oxidation (MSO) is a robust thermal treatment process that can be used to oxidatively and efficiently destroy the organic constituents of mixed and hazardous wastes. An integrated pilot-scale MSO demonstration facility has been installed and operated at Lawrence Livermore National Laboratory (LLNL). This facility, which has been operational since December 1997, was built to demonstrate the capability of processing organic feed at a commercially useful scale ( 5 to $7 \mathrm{~kg}$ per hour). The integrated MSO treatment train consists of several subsystems: a primary MSO processor (reaction vessel), an off-gas conditioning system, a salt recycle system, and a ceramic final forms immobilization system. The MSO/off-gas system began operations in December 1997, while the salt recycle system and the ceramic final forms immobilization system were activated in May 1998 and September 1998, respectively. During FY98, we have successfully conducted tests in the MSO facility on a variety of liquid and solid organic feeds: chlorinated solvents, tributyl phosphate/kerosene mixtures, PCB-contaminated waste oils and solvents, shredded booties and coveralls, plastic pellets, ion-exchange resins, activated carbon, several radioactive-spike organics, and two well-characterized low-level liquid mixed wastes. The results of the demonstration in FY 98 has been documented [1].

In FY99 (October 1998 to April 1999) we conducted further testing in the MSO/off-gas system with ion exchange resins, two real waste specimens, activated carbon, and TNTloaded activated carbon, both at regular feed rates and higher feed rates up to a superficial gas velocity of $1.5 \mathrm{ft} / \mathrm{s}$. We also drained the salt three times (SR7, SR8, SR9) in FY99 and sent the spent salts to the salt recycle system for further processing. This report presents the results obtained from the demonstration of the MSO/off-gas system and the salt recycle system from October 1998 to April 1999. We then shut down the operation, and cleaned the equipment and the facility in May 1999.

Our first demonstration in FY99 was on ion exchange resin after the feed system was modified to deliver resin slurry directly into the MSO process vessel. A stable feed rate was obtained with the modified slurry delivery system. Good off-gas quality was observed with this run. After an annual maintenance and inspection of the MSO and off-gas system in December 1998, the MSO vessel was reloaded with fresh carbonate salt in preparation for a treatability study on low-level mixed waste specimens. The main purpose for conducting this treatability study in FY99 with real waste streams was to determine the highest superficial gas velocity in order to increase throughput. Two real waste specimens were chosen for the treatability studies conducted in FY99. These specimens were received from the Hazardous Waste Management Division at LLNL (waste stream numbers LLW008 and LL-W016). The first specimen (RTS \#3) was PCB-contaminated liquid waste $(60 \mathrm{ppm})$ and the second specimen (RTS\#4) was chlorinated solvents. Both specimens contain traces of metals and low-level of radionuclides such as tritium and gross alpha and gross beta. Five gallons of RTS\#3 and 10 gallons of RTS\#4 were processed through the reactor at $930^{\circ} \mathrm{C}$ with excess air at feed rates up to $2.2 \mathrm{~kg} / \mathrm{hr}$ (RTS\#3) and $7.8 \mathrm{~kg} / \mathrm{hr}$ (RTS\#4) with a superficial gas velocity up to $1.5 \mathrm{ft} / \mathrm{s}$. The off-gas composition was monitored continuously by on-line monitors during the runs, and off-gas samples were taken and analyzed for POHCs, dioxins, and furans. For RTS\#3, the concentrations of $\mathrm{CO}$ and THC in the off-gas were $14.5 \mathrm{ppm}$ and $0.7 \mathrm{ppm}$, respectively, considerably lower than the current standards for mixed-waste incinerators. For the chlorinated solvent waste specimen LL-W008, the off-gas quality was very good, with $\mathrm{NO}_{x}<210 \mathrm{ppm}, \mathrm{CO}<15 \mathrm{ppm}$, and $\mathrm{THC}<0.4 \mathrm{ppm}$. The $\mathrm{NO}_{\mathrm{x}}$ was further reduced to $\mathrm{ppm}$ levels in the catalytic converter POHCs, dioxins and furans were not detectable in the off-gas for the runs. 
After the treatability study in February 1999, the system was tested with activated carbon as the feed. Four different sizes of granular activated carbon were tested: 1.2 to $2.4 \mathrm{~mm}, 0.4$ to $1.4 \mathrm{~mm}, 0.4$ to $0.8 \mathrm{~mm}$, and $<0.15 \mathrm{~mm}$. The vibratory feeder was used to deliver the larger carbon particles into the MSO vessel. The 0.4 to $0.8 \mathrm{~mm}$ size of activated carbon was loaded with $0.5 \mathrm{wt} . \%$ TNT in an effort to simulate a real waste stream from a demilitarization plant. For the finest size of carbon $(<0.15 \mathrm{~mm})$, it was delivered as the water slurry into the MSO vessel. The carbon testing was conducted at $950^{\circ} \mathrm{C}$ with excess air at feed rates up to $2.1 \mathrm{~kg} / \mathrm{hr}$. The off-gas composition was again monitored continuously by on-line monitors during the runs, and off-gas samples for the TNT-loaded carbon run were taken and analyzed for TNT. For the carbon runs, the off-gas quality was very good, with $\mathrm{NO}_{\mathrm{x}}<130 \mathrm{ppm}, \mathrm{CO}<350 \mathrm{ppm}$, and $\mathrm{THC}<0.3 \mathrm{ppm}$. The $\mathrm{NO}_{\mathrm{x}}$ and $\mathrm{CO}$ were further reduced to ppm levels in the catalytic converter. The TNT was not detectable in the off-gas for the TNT-loaded carbon run. Carbon conversion was above $99.9 \%$ with carbon particles smaller than $1.2 \mathrm{~mm}$. Extensive air purge was not required. For carbon particles larger than $1.2 \mathrm{~mm}$, air purge for several hours was required after the feed stopped in order to complete the carbon conversion in the MSO vessel.

The salt recycle system was used again successfully to treat three batches of spent salt generated from the MSO processor during FY99. These salt (SR7, SR8, SR9) consisted of mostly sodium carbonate with traces of sodium chloride, sodium fluoride, sodium phosphate, sodium sulfate along with ashes and some metals such as nickel and chromium. After the salt recycle, all the nickel was removed and more than $90 \%$ of chromium in the spent salt was removed in the salt recycle system, resulting in clean salt solution with ppm levels of chromium.

Since May of 1997, the vessel has been inspected three times. The vessel was inspected with an ultrasonic meter at various locations along the vessel wall. The inspection result showed that the corrosion rate was only 0.0027 inches per 100 hours of operation at temperature above 900 degree $C$ in the beginning and that it dropped to 0.0011 inches $/ 100$ hrs. At this corrosion rate, a MSO vessel with a $1 / 2$ inch thick wall would be able to operate for 25000 hours. For a MSO treatment plant operating 5000 hours a year, the MSO vessel would last for 5 years before a replacement vessel is needed.

On the basis of the demonstrations conducted in FY98 and FY99, we have established that MSO is a mature, versatile and effective technology for the treatment of the following classes of organic-based hazardous and mixed wastes: halogenated solvents and refrigerants, PCB-contaminated oils and solvents, solutions of actinide complexants in nonhalogenated solvents, ion-exchange resins, granulated activated carbon loaded with TNT, and uranium-contaminated organics. Thus, as a viable alternative to incineration, MSO could provide a solution to many vexing waste disposal problems that continue to exist around the DOE complex and DOD military installations. 


\section{INTRODUCTION}

MSO is a promising alternative to incineration for the treatment of a variety of organic wastes. Lawrence Livermore National Laboratory (LLNL) has prepared a facility in which an integrated pilot-scale MSO treatment system is being tested and demonstrated. The system consists of a MSO vessel with a dedicated off-gas treatment system, a salt recycle system, feed preparation equipment, and a ceramic final waste forms immobilization system. This integrated system was designed and engineered based on operational experience with an engineering-scale reactor unit and extensive laboratory development on salt recycle and final forms preparation.

The MSO/off-gas system has been operational since December 1997. The salt recycle system and the ceramic final forms immobilization became operational in May 1998. In FY98, we have tested the MSO facility with various organic feeds, including chlorinated solvents, tributyl phosphate/kerosene, PCB-contaminated waste oils \& solvents, booties, plastic pellets, ion exchange resins, activated carbon, radioactive-spiked organics, and well-characterized low-level liquid mixed wastes. MSO is shown to be a versatile technology for hazardous waste treatment and may be a solution to many waste disposal problems in DOE sites. The results of the demonstration conducted in FY98 has been reported [1].

In FY99 (October 1998 to April 1999) we conducted further testing in the MSO/off-gas system with ion exchange resins, two real waste specimens, activated carbon, and TNTloaded activated carbon, both at regular feed rates and higher feed rates up to a superficial gas velocity of $1.75 \mathrm{ft} / \mathrm{s}$. We also drained the salt three times (SR7, SR8, SR9) in FY99 and sent the spent salts to the salt recycle system for further processing. This report presents the results obtained from the demonstration of the MSO/off-gas system and the salt recycle system from October 1998 to April 1999. We then shut down the operation and cleaned the equipment and the facility in May 1999.

\section{PROCÉSS DESCRIPTION}

MSO is a robust thermal treatment process for destroying organic waste. In this process, organic -containing wastes are injected with a stoichiometric excess of oxidant air under a pool of molten carbonate salts at temperatures between $700-950^{\circ} \mathrm{C}$. Flameless oxidation takes place within the salt bath converting the organic components of the waste into $\mathrm{CO}_{2}$, $\mathrm{N}_{2}$, and water. The product off-gas leaving the processor is treated to remove any entrained salt particulate and essentially all water vapor before being discharged to the facility off-gas system. Halogens and heteroatoms such as sulfur are converted into acid gases, which are then "scrubbed" and trapped in the salt in forms such as $\mathrm{NaCl}$ and $\mathrm{Na}_{2} \mathrm{SO}_{4}$. Using sodium carbonate in the processor, this process occurs according to the reaction shown in Equations 1, 2, 3, and 4, where $X$ represents generic halogens.

$$
2 \mathrm{C}_{\mathrm{a}} \mathrm{H}_{\mathrm{b}}+(2 \mathrm{a}+\mathrm{b} / 2) \mathrm{O}_{2}---->2 \mathrm{aCO}_{2}+\mathrm{bH}_{2} \mathrm{O}
$$

For nitrogen -bearing organic wastes,

$$
\mathrm{C}_{\mathrm{a}} \mathrm{H}_{\mathrm{b}} \mathrm{N}_{\mathrm{c}}+\mathrm{O}_{2}-\cdots \mathrm{CO}_{2}+\mathrm{H}_{2} \mathrm{O}+\mathrm{N}_{2}+\mathrm{NO}_{\mathrm{x}}
$$

For halogenated organic wastes,

$$
\mathrm{C}_{\mathrm{a}} \mathrm{H}_{\mathrm{b}} \mathrm{X}_{\mathrm{c}}+\mathrm{c} / 2 \mathrm{Na}_{2} \mathrm{CO}_{3}+(\mathrm{a}+(\mathrm{b}-\mathrm{c}) / 4) \mathrm{O}_{2}--->(\mathrm{a}+\mathrm{c} / 2) \mathrm{CO}_{2}+\mathrm{b} / 2 \mathrm{H}_{2} \mathrm{O}+\mathrm{cNaX}
$$

For sulfur-containing organic wastes, 


$$
\mathrm{C}_{\mathrm{a}} \mathrm{H}_{\mathrm{b}} \mathrm{S}_{\mathrm{c}}+\mathrm{cNa}_{2} \mathrm{CO}_{3}+(\mathrm{a}+\mathrm{b} / 4+3 \mathrm{c} / 2) \mathrm{O}_{2}--->(\mathrm{a}+\mathrm{c}) \mathrm{CO}_{2}+\mathrm{b} / 2 \mathrm{H}_{2} \mathrm{O}+\mathrm{cNa}_{2} \mathrm{SO}_{4}
$$

Other non-oxidizable inorganic constituents, heavy metals, and radionuclides are held captive in the salt, either as metals or oxides, and are easily separated for disposal.

MSO has several unique characteristics. The large thermal mass of the molten salt provides a stable heat-transfer medium that resists thermal surges and ensures temperature uniformity and is therefore able to tolerate rapid process fluctuations. Flame-outs are completely avoided, since MSO is a non-flame process that proceeds by catalytic liquidphase oxidation reactions. Operation of the MSO system is at temperatures hundreds of degrees lower than flame combustion temperatures, which, among other things, minimizes emissions of the radioactive materials from mixed wastes. Acid gases are "scrubbed" by the alkali salts, eliminating the need for a wet off-gas scrubbing system.

\section{SYSTEM DESCRIPTION}

The integrated MSO system, shown in Fig. 1, consists of several subsystems. It includes a reaction vessel, an off-gas treatment system, a salt recycle system, feed preparation equipment, as well as ceramic final waste forms immobilization system. The feed preparation area includes waste receiving drums, centrifuge for solid liquid separation, a shredder for size-reducing solid wastes such gloves, booties etc. The waste is fed to the reaction vessel along with oxidant air using a top-feed injection system designed for solid and liquid waste streams at throughputs up to $7 \mathrm{~kg} / \mathrm{hr}$ for chlorinated solvents. Product off-gas exiting the vessel is then treated in the off-gas system to remove entrained salt particulates, water vapor, and traces of gas species such as $\mathrm{CO}$ and $\mathrm{NO}_{\mathbf{x}}$, As waste is injected into the MSO vessel, residues of inorganic components build up in the salt bed which necessitates periodic removal of salt and replenishment with fresh salt to maintain process efficiency. Because many of the metals and/or radionuclides captured in the salt are hazardous and/or radioactive, without further treatment the removed spent salt would create a large secondary waste stream. A salt recycle system is needed to segregate these materials to minimize the amount of secondary waste, and to reduce the consumption of fresh salt [2]. The segregated inorganic residues are then immobilized as a ceramic final form for disposal. For detailed description of each subsystem, please visit our MSO website at www-ep.es.llnl.gov/www-ep/aet/waste/wt.html.

\section{EXPERIMENTS IN THE MSO/OFF-GAS SYSTEM RESULTS}

\subsection{Schedule}

Several demonstrations were conducted in the MSO/off-gas system with ion exchange resins in October and November 1998, for a treatability study with real waste specimens in January and February 1990, and with activated carbon and TNT in March and April 1999. The facility was then orderly shut down and cleaned in May 1999. The operational schedule of the integrated facility in FY99 is shown in Table 1.

Table 1: Operational Schedule of the MSO Facility in FY99

Month Activity

October

Feed system modification for ion exchange resin slurry

November

MSO demo with ion exchange resin slurry 
Fig. 1 Integrated MSO System

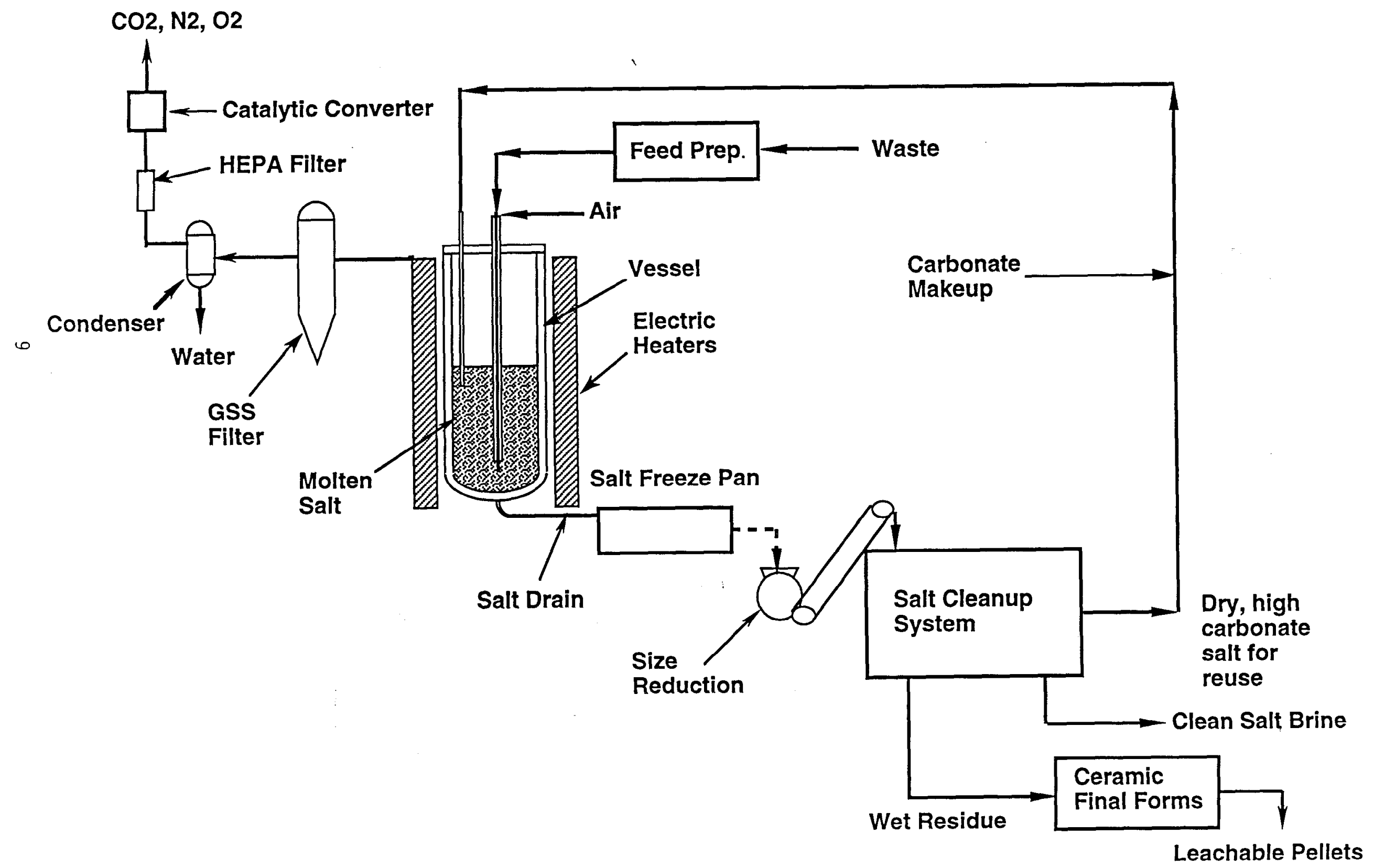


December

January

February

March

April

May
Inspection and calibration of the MSO/off-gas system

$1^{\text {st }}$ Treatability study with real waste specimen, RTS\#3

$2^{\text {nd }}$ Treatability study with real waste specimen, RTS\#4

MSO demo with activated carbon

MSO demo with TNT-loaded activated carbon

Detailed description of each experiment and result follow.

\subsection{MSO Demonstration with Ion Exchange Resin Slurry}

Nuclear industry generates large quantities of spent ion exchange resins each year. Although some of the spent resins can be regenerated and reused, most of the spent resins has to be properly discarded or treated. It is either a low level mixed waste or a low-level waste and represents an ideal feed stream for the demonstration of MSO technology.

In FY98, a limited MSO demonstration with dry ion exchange was conducted in test series III. The resin was fed into the process vessel with a vibratory feeder with excess air to overcome the feed rate fluctuation. Since most spent resins are wet, an extensive effort was made to modify the feed system for delivery of wet resin into the process vessel. The resin can be diluted in a liquid carrier such as mineral oil or water and pumped into the reactor. Figure 2 shows the resin slurry feed system. The resin was pumped around the feed container under mixing while a slipstream of slurry was withdrawn. A small metering pump then deliver the slurry into the process vessel along with the driver air. Occasional liquid purges were needed to avoid plugging the feed line. The results showed that the slurry feed system was able to deliver a consistent feed to the MSO vessel. Table 2 shows the run conditions.

Table 2: Resin Slurry Demonstration

\begin{tabular}{cll} 
Run Number & Resin Loading & Conditions \\
1 & $20 \mathrm{wt} . \%$ Amberlite & $2.0 \mathrm{~kg} / \mathrm{hr}, 950 \mathrm{C}, 30 \%$ excess air \\
2 & $35 \mathrm{wt} \%$ Amberlite & $1.83 \mathrm{~kg} / \mathrm{hr}, 950 \mathrm{C}, 45 \%$ excess air \\
\hline
\end{tabular}

During the slurry demonstration, all the process data including gas compositions were recorded. Some gas samples for run 1 were also collected and sent to a laboratory for analysis. The off-gas composition for these runs is shown in Table 3. 


\section{- FIGURE 2}

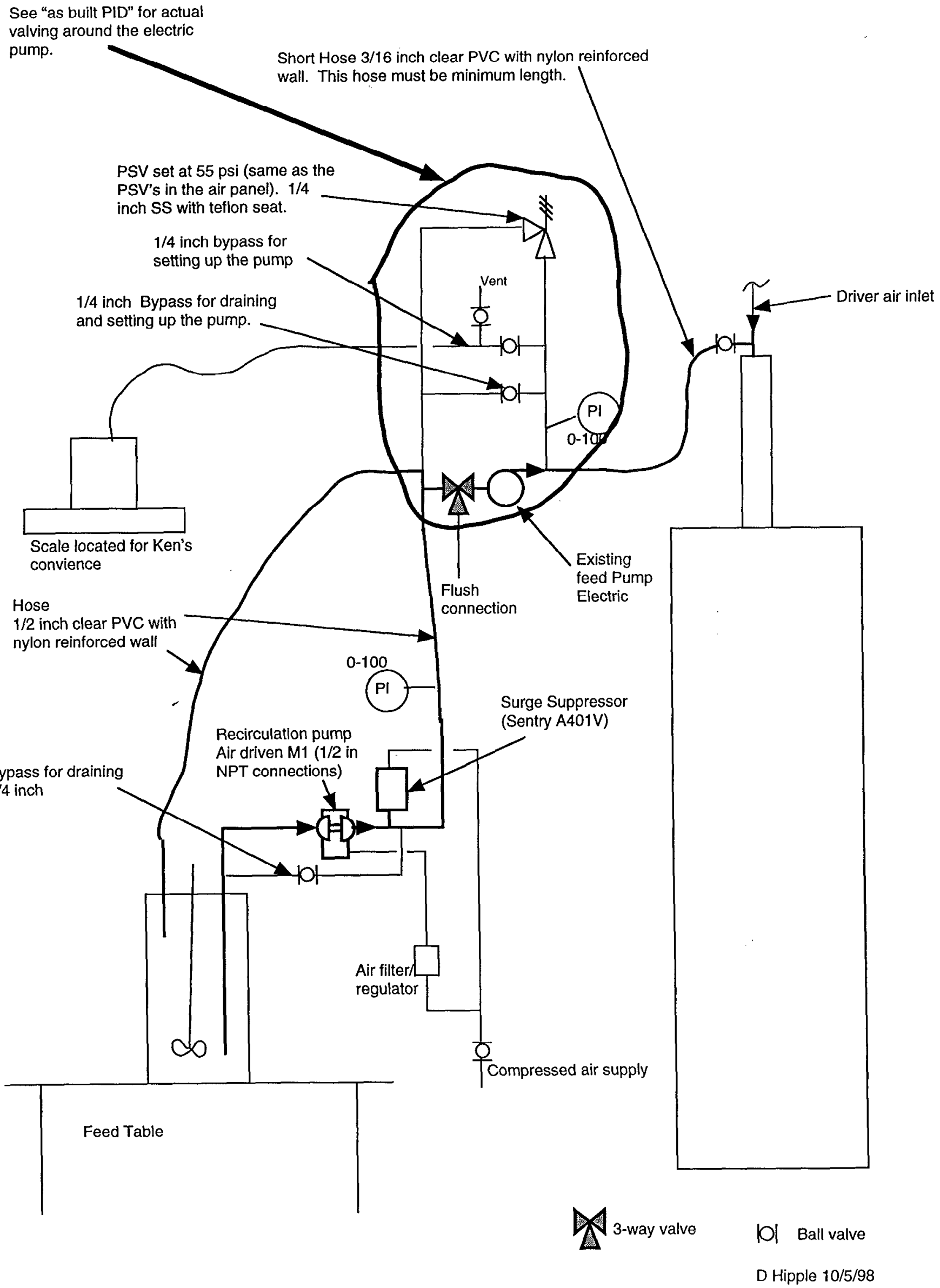


Table 3: Off-gas Composition

\begin{tabular}{cll} 
& \multicolumn{2}{l}{ Run Numbers } \\
\cline { 2 - 3 } Off-gas Species & \multicolumn{2}{l}{2} \\
\hline $\mathrm{CO}_{2}, \%$ & 9.0 & 8.4 \\
$\mathrm{O}_{2}, \%$ & 8.0 & 9.2 \\
$\mathrm{CO}, \mathrm{ppm}$ & 17.1 & 14.5 \\
$\mathrm{NO}_{\mathrm{x}}, \mathrm{ppm}$ & 123 & 130 \\
$\mathrm{SO}_{\mathrm{x}}$ & 0.0 & 0.0 \\
$\mathrm{THC}$ & 0.17 & 0.0 \\
\hline
\end{tabular}

The values in Table 3 were taken from the off-gas analyzer readings at steady state. Figure 3 shows the off-gas composition for Run 1. The spikes were the result of feed line purges with the liquid carrier. The concentration of $\mathrm{CO}_{2}$ and $\mathrm{O}_{2}$ in the off-gas were fairly constant, an indication of stable operation. Good off-gas quality was observed in all the runs. Attempts to increase resin slurry loading above $40 \mathrm{wt} . \%$ failed because the feed pump clogged.

\subsection{FY99 Treatability Studies (RTS\#3, RTS\#4)}

\subsubsection{Description}

One of main purposes for conducting the treatability study in FY99 with real waste streams was to determine the highest superficial gas velocity in order to increase throughput of the MSO vessel. Two popular real waste specimens were chosen for the MSO treatability study in FY99. These specimens were received from the Hazardous Waste Management (HWM) Division at LLNL (waste stream numbers LL-W008 and LL-W016). The first specimen (RTS \#3) was PCB-contaminated liquid wastes and the second specimen was chlorinated solvents. Both specimens contain traces of metals and low-level of radionuclides such as tritium and gross alpha and gross beta. Table 4 shows the composition of these two specimens.

\subsubsection{Results of MSO Demonstration with RTS\#3 (LL-W016)}

Five gallons of the RTS\#3 specimen were received from HWM in early January. Toluene was then added to the feed container under mixing to prevent phase separation during feeding to the MSO vessel. The demonstration was conducted at superficial gas velocities as high as $1.5 \mathrm{ft} / \mathrm{s}$ at $930^{\circ} \mathrm{C}$ and $950^{\circ} \mathrm{C}$, respectively. Twenty percent excess air was used for the oxidation to avoid excessive pressure drops across the GSS filter. Off-gas was monitored continuously by off-gas analyzers installed in the off-gas system during the course of the demonstration. In addition to the continuous off-gas monitoring, several gas samples were collected and sent to the environmental chemistry laboratory at LLNL for analysis. Tables 5 and 6 show the run conditions and the off-gas compositions, respectively. 
Fig. 3 Off gas data for Ion Exchange/mineral Oil slurry feed

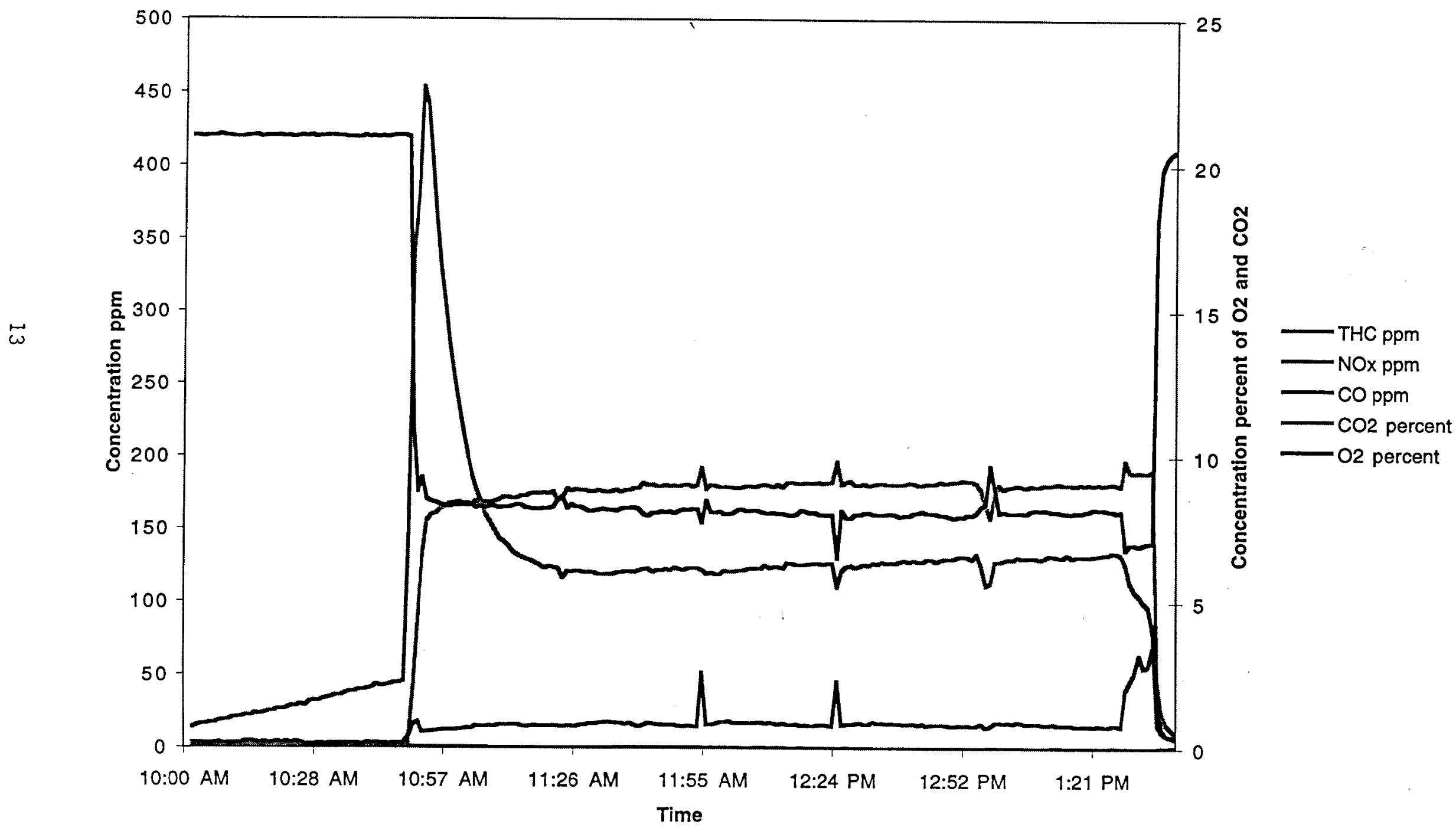


Table 4

Real Test Specimens for MSO Treatability Study in FY98

\begin{tabular}{|c|c|c|}
\hline & $\begin{array}{l}\text { RTS \#3 } \\
\text { Chlorosolvent } \\
\text { LL-W016 }\end{array}$ & $\begin{array}{l}\text { RTS \#4 } \\
\text { Chlorosolvent } \\
\text { LL-W008 }\end{array}$ \\
\hline chloroform (g/L) & 2.81 & 0.1 \\
\hline 1,1-dichloroethane $(\mathrm{g} / \mathrm{L})$ & 7.09 & 0.5 \\
\hline 1,2-dichloroethane $(\mathrm{g} / \mathrm{L})$ & 3.0 & 0.5 \\
\hline 1,1 -dichloroethene $(\mathrm{g} / \mathrm{L})$ & ND & 20 \\
\hline dichloromethane $(\mathrm{g} / \mathrm{L})$ & ND & 1.4 \\
\hline Benzene & 9.05 & ND \\
\hline Xylene & 11.6 & ND \\
\hline 2-butanone & 12.3 & ND \\
\hline Ethyl benzene & 3.4 & ND \\
\hline $\begin{array}{l}\text { tetrachloroethane }(\mathrm{g} / \mathrm{L}) \\
\text { toluene }(\mathrm{g} / \mathrm{L})\end{array}$ & & 40 \\
\hline toluene $(g / L)$ & 25.4 & 0.1 \\
\hline Methylene chloride & 16.5 & ND \\
\hline trichloroethene $(\mathrm{g} / \mathrm{L})$ & 1.41 & 10 \\
\hline $1,1,2$-trichloro, $1,2,2$ trifluoroethane $(\mathrm{g} / \mathrm{l})$ & ND & 28 \\
\hline methylchloroform (g/L) & 219 & 1226 \\
\hline $\mathrm{Sb}(\mathrm{mg} / \mathrm{L})$ & NA & 0 \\
\hline $\mathrm{Ba}(\mathrm{mg} / \mathrm{L})$ & NA & 1.5 \\
\hline $\mathrm{Be}(\mathrm{mg} / \mathrm{L})$ & NA & 8.2 \\
\hline $\mathrm{Cd}(\mathrm{mg} / \mathrm{L})$ & NA & 0 \\
\hline $\mathrm{Cr}(\mathrm{mg} / \mathrm{L})$ & NA & 1.3 \\
\hline $\mathrm{Co}(\mathrm{mg} / \mathrm{L})$ & $\mathrm{NA}$ & 0.2 \\
\hline $\mathrm{Cu}(\mathrm{mg} / \mathrm{L})$ & NA & 11 \\
\hline $\mathrm{Pb}(\mathrm{mg} / \mathrm{L})$ & NA & 11 \\
\hline $\mathrm{Mo}(\mathrm{mg} / \mathrm{L})$ & NA & 2.5 \\
\hline $\mathrm{Ni}(\mathrm{mg} / \mathrm{L})$ & NA & 2 \\
\hline $\mathrm{K}(\mathrm{mg} / \mathrm{L})$ & NA & 4 \\
\hline $\mathrm{Ag}(\mathrm{mg} / \mathrm{L})$ & $\mathrm{NA}$ & 0.3 \\
\hline $\mathrm{U}(\mathrm{mg} / \mathrm{L})$ & NA & 20 \\
\hline$V(\mathrm{mg} / \mathrm{L})$ & NA & 3.1 \\
\hline $\mathrm{Zn}(\mathrm{mg} / \mathrm{L})$ & NA & 5.3 \\
\hline $\mathrm{Hg}(\mathrm{mg} / \mathrm{L})$ & $\mathrm{Na}$ & 0.04 \\
\hline hydraulic oil, $(\mathrm{g} / \mathrm{L})$ & balance & None \\
\hline $\mathrm{PCB}, \mathrm{mg} / \mathrm{L}$ & 61 & None \\
\hline Gross Alpha (nCi/L) & 7.26 & 7.26 \\
\hline Gross Beta $(n C i / L)$ & 11.4 & 11.4 \\
\hline (Tritium $(\mathrm{nC} / \mathrm{L})$ ) & 33.1 & 33.1 \\
\hline
\end{tabular}


Table 5: Run Conditions for MSO Demo with RTS\#3

No. Feeds Superficial gas velocity Run Conditions

$3 \mathrm{~A}$

RTS\#3/Toluene

$1.0 \mathrm{ft} / \mathrm{s}$

$950^{\circ} \mathrm{C}, 1.44 \mathrm{~kg} / \mathrm{hr}, 20 \%$ excess air

$3 \mathrm{~B}$

RTS\#3/Toluene

$1.5 \mathrm{ft} / \mathrm{s}$

$950^{\circ} \mathrm{C}, 2.16 \mathrm{~kg} / \mathrm{hr}, 20 \%$ excess air

$3 \mathrm{C}$

RTS\#3/Toluene

$1.5 \mathrm{ft} / \mathrm{s}$

3D

RTS\#3/Toluene

$1.0 \mathrm{ft} / \mathrm{s}$

$930^{\circ} \mathrm{C}, 2.10 \mathrm{~kg} / \mathrm{hr}, 20 \%$ excess air

$930^{\circ} \mathrm{C}, 1.44 \mathrm{~kg} / \mathrm{hr}, 20 \%$ excess air

Table 6: Off-gas Composition for the MSO Demo with RTS\#3

\begin{tabular}{lllll} 
& \multicolumn{4}{c}{ Run Numbers } \\
\cline { 2 - 5 } Off-gas Species & $3 \mathrm{~A}$ & $3 \mathrm{~B}$ & $3 \mathrm{C}$ & $3 \mathrm{D}$ \\
\hline $\mathrm{CO}_{2}, \%$ & 9.73 & 9.60 & 10.08 & 9.46 \\
$\mathrm{O}_{2}, \%$ & 8.06 & 7.26 & 9.82 & 8.01 \\
$\mathrm{CO}, \mathrm{ppm}$ & 9.9 & 14.5 & 11.7 & 14.0 \\
$\mathrm{NO}_{x}, \mathrm{ppm}$ & 113 & 97.7 & 110.5 & 100.5 \\
THC. ppm & 0.29 & 0.62 & $0.0^{*}$ & $0.0^{*}$ \\
\hline
\end{tabular}

*The off-gas analyzers drifted down during the course of the run.

Table 6 shows that off-gas quality was very good with less than $15 \mathrm{ppm}$ of $\mathrm{CO}$ and less than 120 ppm of $\mathrm{NO}_{\mathrm{x}}$ leaving the MSO vessel, respectively. It also indicates that operating at the higher flow gas velocity of $1.5 \mathrm{ft} / \mathrm{s}$ and lower temperature $\left(930^{\circ} \mathrm{C}\right)$ would not adversely affect the off-gas quality. $\mathrm{CO}$ and $\mathrm{NO}_{\mathrm{x}}$ levels in the off-gas were further reduced to undetectable levels in the catalytic converter. The presence of POHCs (principle organic hazardous compounds) such as dioxins in the off-gas could not be detected, as shown in Table 7.

\subsubsection{Results of MSO Demonstration with RTS\#4 (LL-W008)}

Ten gallons of the RTS\#4 specimen was received from HWM in early January. There were two liquid phases in the containers. The top layer $(15 \mathrm{wt} \%)$ contained mostly water and the bottom layer ( $85 \mathrm{wt} \%$ ) contained chlorinated solvents and a small amount of sludge. The demonstration was conducted at superficial gas velocities as high as $1.5 \mathrm{ft} / \mathrm{s}$ at $930^{\circ} \mathrm{C}$. $30 \%$ and $20 \%$ excess air were used for the oxidation to avoid excessive pressure drops across the GSS filter. Lower temperature $\left(930^{\circ} \mathrm{C}\right)$ reduces the salt vapor carryover to the off-gas system but may decrease the destruction efficiency. Off-gas was monitored continuously by off-gas analyzers installed in the off-gas system during the course of the demonstration. In addition to the continuous off-gas monitoring, several gas samples were collected during the course of the demonstration and sent for analysis. Tables 8 and 9 show the run conditions and the off-gas compositions, respectively. 
ANALYTICAL INFORMATION

\begin{tabular}{|c|c|c|c|c|c|c|c|c|c|}
\hline & & & & & & 接 & 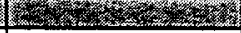 & 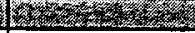 & 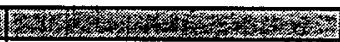 \\
\hline Lab Log \# & $\begin{array}{c}\text { Sample } \\
\text { Identification }\end{array}$ & $\begin{array}{c}\text { COC } \\
\#\end{array}$ & Sampler & $\begin{array}{c}\text { Time } \\
\text { Sampled }\end{array}$ & $\begin{array}{c}\text { Date } \\
\text { Sampled }\end{array}$ & $\begin{array}{c}\text { Date } \\
\text { Recelved }\end{array}$ & $\begin{array}{c}\text { Date } \\
\text { Analyzed }\end{array}$ & Analyst & $\begin{array}{c}\text { Detection } \\
\text { Limits } \mu g / \mathrm{L}\end{array}$ \\
\hline 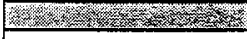 & 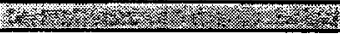 & 2 & 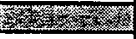 & 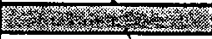 & 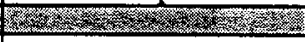 & - & S6rom & $2 x+7=2$ & 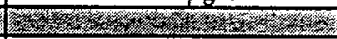 \\
\hline EC99001-0021 & MS-12 & N/A & $\mathbf{K F}$ & $\mathrm{N} / \mathrm{A}$ & $1 / 20 / 99$ & $1 / 20 / 99$ & $1 / 20199$ & $\mathrm{KC}$ & $0.200 \mathrm{ppm}$ \\
\hline EC99001-0022 & MS-1 & N/A & $\mathbf{K F}$ & $\mathbf{N} / \mathbf{A}$ & $1 / 2009$ & $1 / 20199$ & $1 / 20 / 99$ & $\mathbf{K C}$ & $0.200 \mathrm{ppmr}$ \\
\hline EC99001-0027 & MS-16 & N/A & $\mathbf{K F}$ & N/A & $1 / 20199$ & $1 / 20199$ & $1 / 20199$ & $\mathbf{K C}$ & $0.200 \mathrm{ppmv}$ \\
\hline
\end{tabular}

ANALYTICAL RESULTS

\begin{tabular}{|c|c|c|c|c|c|c|c|c|}
\hline & 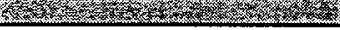 & 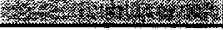 & & & & 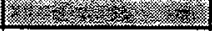 & $48-2<1$ - & 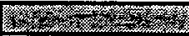 \\
\hline Lab Log \# & $\begin{array}{c}\text { Sample } \\
\text { Identification }\end{array}$ & $\begin{array}{c}\text { PCB } \\
\text { ng }\end{array}$ & $\begin{array}{c}\text { Toluene } \\
\text { ng }\end{array}$ & $\begin{array}{c}\mathrm{C}-10 \text { to } \mathrm{C}-14 \\
\mathrm{ng}\end{array}$ & $\begin{array}{c}\text { 1,1,1-Trichloroethane } \\
\text { ng }\end{array}$ & $\begin{array}{l}\text { Furans } \\
\text { ng }\end{array}$ & $\begin{array}{c}\text { Dioxanes } \\
\text { ng }\end{array}$ & Comments \\
\hline 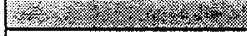 & 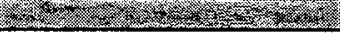 & 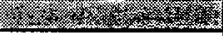 & 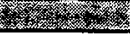 & (20) & 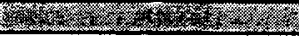 & 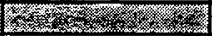 & 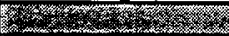 & 107. \\
\hline EC99001-0021 & MS-12*** & ND* & ND & ND. & ND & ND & ND & RTS-3 \\
\hline EC99001-0022 & MS-1*t*** & ND & $\mathrm{ND}$ & $\mathrm{ND}$ & $\mathrm{ND}$ & $\mathrm{ND}$ & ND & RTS-3 \\
\hline EC99001-0027 & MS-16 & ND & ND & ND & $\mathrm{ND}$ & ND & ND & RTS-3 \\
\hline
\end{tabular}

: $\mathrm{ND}=\mathrm{Not}$ detected at or above limit of dercesion

**Supelco Carbotrap 300 (Carbotrap C, Carbotrap B. \& Carbosieve S-III)

***Received with Thermal Desorption Tube Broken. Data compromised when sample transferred to new tube for analysis.

****Received with the Carbosieve S-III missing from Tube. Sample run as received

Please contact Marina Chiarappa at 2-2144 if you have any questions regarding this report.

ND $=$ non-detectable 
Table 8: Run Conditions for MSO Demo with RTS\#4

No. Feeds Superficial gas velocity Run Conditions

4A RTS\#4, bottom layer $\quad 1.0 \mathrm{ft} / \mathrm{s} \quad 930^{\circ} \mathrm{C}, 5.1 \mathrm{~kg} / \mathrm{hr}, 30 \%$ excess air

4B RTS\#4, bottom layer $\quad 1.5 \mathrm{ft} / \mathrm{s} \quad 930^{\circ} \mathrm{C}, 7.8 \mathrm{~kg} / \mathrm{hr}, 30 \%$ excess air

4C RTS\#4, bottom layer $\quad 1.4 \mathrm{ft} / \mathrm{s} \quad 930^{\circ} \mathrm{C}, 7.8 \mathrm{~kg} / \mathrm{hr}, 20 \%$ excess air

Table 9: Off-gas Composition for the MSO Demo with RTS\#4

\begin{tabular}{llll} 
& \multicolumn{3}{c}{ Run Numbers } \\
\cline { 2 - 4 } Off-gas Species & $4 \mathrm{~A}$ & $4 \mathrm{~B}$ & $4 \mathrm{C}$ \\
\hline $\mathrm{CO}_{2}, \%$ & 14.9 & 15.6 & 18.3 \\
$\mathrm{O}_{2}, \%$ & 9.0 & 8.5 & 6.7 \\
$\mathrm{CO}, \mathrm{ppm}$ & 14.3 & 8.2 & 9.8 \\
$\mathrm{NO}_{\mathrm{x}}, \mathrm{ppm}$ & 169 & 209 & 212 \\
$\mathrm{THC}, \mathrm{ppm}$ & 0.34 & $0.0^{*}$ & $0.0^{*}$ \\
\hline
\end{tabular}

*The off-gas analyzers drifted down during the course of the run.

Table 9 shows that off-gas quality was very good with less than 15 ppm of CO and less than $220 \mathrm{ppm}$ of $\mathrm{NO}_{\mathrm{x}}$ leaving the MSO vessel, respectively. It also indicates that operating at the higher flow gas velocity of $1.5 \mathrm{ft} / \mathrm{s}$ and lower temperature $\left(930^{\circ} \mathrm{C}\right)$ would not adversely affect the off-gas quality. $\mathrm{CO}$ and $\mathrm{NO}_{\mathrm{x}}$ levels in the off-gas were further reduced to undetectable levels in the catalytic converter. The concentrations of POHCs (principle organic hazardous compounds) such as dioxins in the off-gas were not detectable, as shown in Table 10. The results demonstrated that as high as $8 \mathrm{~kg} / . \mathrm{hr}$ of chlorinated solvent can be treated in a single vessel with a 12" nominal diameter .

\subsection{Demonstration with Activated Carbon and TNT-loaded Activated Carbon}

The MSO demonstration with activated carbon was based on the collaboration between the EM MSO team and the DOD MSD team at LLNL. A granular activated carbon, 8 to 14 mesh size, was used as the surrogate feed. The activated carbon was fed for 4 hours at 1.5 $\mathrm{kg} / \mathrm{hr}$ followed by a 9 hours of air purge. Composition of off-gas was closely monitored with off-gas analyzers. Molten salt samples were taken during the course of demonstration and were sent for carbon analysis. It was found that the instantaneous efficiency of conversion of carbon feed to $\mathrm{CO}_{2}$ slowly increased with time, reaching approximately $80 \%$ after 4 hours. However the overall conversion efficiency of $\mathrm{C}$ to $\mathrm{CO}_{2}$ at this time was considerably lower, probably due to the size of carbon particles, and we found the only way to increase it was by stopping the $C$ feed but continuing to purge air through the reactor. Carbon analyses on salt samples taken after air purging for 2 hours and 9 hours 
ANALYTICAL INFORMATION

\begin{tabular}{|c|c|c|c|c|c|c|c|c|c|}
\hline (2) & 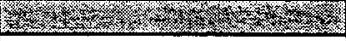 & 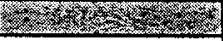 & 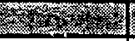 & 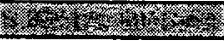 & 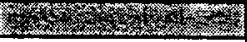 & 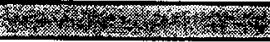 & 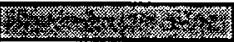 & (1) & 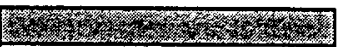 \\
\hline Lab Log \# & $\begin{array}{c}\text { Sample } \\
\text { Identification }\end{array}$ & $\begin{array}{c}\text { COC } \\
\#\end{array}$ & Sampler & $\begin{array}{c}\text { Time } \\
\text { Sampled }\end{array}$ & $\begin{array}{c}\text { Date } \\
\text { Sampled }\end{array}$ & $\begin{array}{c}\text { Date } \\
\text { Received }\end{array}$ & $\begin{array}{c}\text { Date } \\
\text { Analyzed }\end{array}$ & Analyst & $\begin{array}{c}\text { Detection } \\
\text { Limits } \mu g / \mathrm{L}\end{array}$ \\
\hline 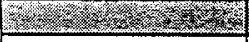 & 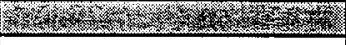 & 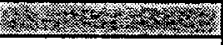 & $2 x-2 x+2$ & 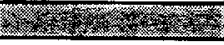 & 6.8.8. & 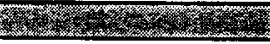 & 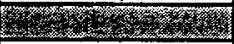 & Her & N-6ry \\
\hline EC99001-0054 & MS-1 & N/A & $\mathbf{K F}$ & $N / A$ & $1 / 27 / 99$ & $1 / 28 / 99$ & $1 / 29199$ & $\mathbf{K C}$ & $23 \mathrm{ng}$ \\
\hline EC99001-0055 & MS-2 & $N / A$ & $\mathbf{K F}$ & N/A & $1 / 27 / 99$ & $1 / 28 / 99$ & $1 / 29 / 99$ & $\mathbf{K C}$ & $25 \mathrm{ng}$ \\
\hline EC99001-0056 & MS-4 & N/A & $\mathbf{K F}$ & N/A & $1 / 27 / 99$ & $1 / 28 / 99$ & $1 / 29199$ & $\mathbf{K C}$ & $25 \mathrm{ng}$ \\
\hline EC99001-0057 & MS-5 & N/A & $\mathbf{K F}$ & N/A & $1 / 27 / 99$ & $1 / 28199$ & $1 / 29 / 99$ & $\mathbf{K C}$ & $25 \mathrm{ng}$ \\
\hline EC99001-0058 & MS-6 & $\mathbf{N} / \mathbf{A}$ & $\mathbf{K F}$ & $\mathbf{N} / \mathbf{A}$ & $1 / 2899$ & $1 / 28199$ & $1 / 30199$ & $\mathrm{KC}$ & $25 \mathrm{mz}$ \\
\hline EC99001-0059 & MS-7 & $\mathrm{N} / \mathrm{A}$ & $\mathbf{K F}$ & $\mathbf{N} / \mathbf{A}$ & $1 / 28199$ & $1 / 2899$ & $1 / 30199$ & $\mathrm{KC}$ & $25 \mathrm{ng}$ \\
\hline EC99001-0060 & MS-8 & N/A & $\mathbf{K r}$ & $\mathbf{N} / \mathbf{A}$ & $1 / 2899$ & $1 / 2899$ & $120 / 99$ & $\mathbf{K C}$ & $25 \mathrm{ng}$ \\
\hline EC99001-0061 & MS-9 & N/A & $\mathbf{K F}$ & N/A & $1 / 28199$ & $1 / 2899$ & 1/30/99 & $\mathbf{K C}$ & $25 \mathrm{ng}$ \\
\hline
\end{tabular}

\section{ANALYTICAL RESULTS}

\begin{tabular}{|c|c|c|c|c|c|c|c|c|c|}
\hline 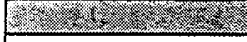 & ferly & 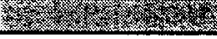 & 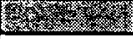 & (6) & 2) & 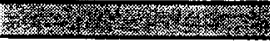 & 10. & CX & Y \\
\hline Lab Log \# & $\begin{array}{c}\text { Sample } \\
\text { Identification }\end{array}$ & \begin{tabular}{|c|} 
Dichloroethylene \\
ng
\end{tabular} & \begin{tabular}{|c|}
$\begin{array}{c}\text { Freon } 113 \\
\text { ng }\end{array}$ \\
\end{tabular} & $\begin{array}{c}\text { Tetrachloroethane } \\
\text { ng }\end{array}$ & $\begin{array}{c}\text { Trichloroethylene } \\
\text { ng }\end{array}$ & $\begin{array}{c}\text { 1,1,1-Trichloroethane } \\
\text { ng }\end{array}$ & $\begin{array}{c}\text { Furans } \\
\text { ng }\end{array}$ & $\begin{array}{c}\text { Dioxanes } \\
\text { ng }\end{array}$ & Comments \\
\hline 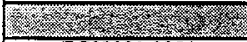 & 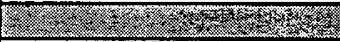 & 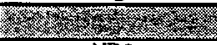 & 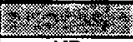 & 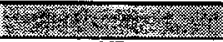 & 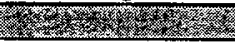 & 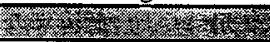 & 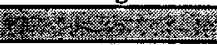 & 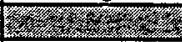 & 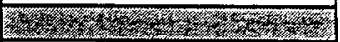 \\
\hline EC99001-0054 & MS-1*+*4 & $\mathrm{ND}^{*}$ & ND & ND & ND & ND & ND & ND & RTS- $4 \mathrm{~B}$ For entire rua \\
\hline EC99001-0055 & MS-2****4 & $\mathrm{ND}$ & ND & $\overline{\mathrm{ND}}$ & $\mathrm{ND}$ & ND & ND & ND & End of 1 st hour \\
\hline EC99001-0056 & $M S-4 \times 4=2$ & ND & ND & ND & ND & $\mathrm{ND}$ & $\mathrm{ND}$ & ND & End of 2 ad bour \\
\hline EC99001-0057 & MS-5****** & ND & $\mathrm{ND}$ & $\mathrm{ND}$ & ND & ND & ND & ND & Only 10 minutes \\
\hline EC99001-0058 & $\frac{M S-6+* *}{M S E}$ & ND & ND & $\mathrm{ND}$ & ND & ND & ND & ND & RTS-4A For entire run \\
\hline EC99001-0059 & MS-7**** & $\mathrm{ND}$ & ND & ND & ND & ND & ND & ND & End of ist bour \\
\hline EC99001-0060 & MS-8*** & ND & ND & ND & ND & ND & ND & ND & End of 2 ad hour \\
\hline EC99001-0061 & MS-9*a* & ND & ND & ND & ND & ND & ND & $\mathrm{ND}$ & End of 3त्d hour \\
\hline 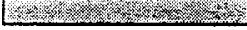 & 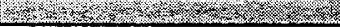 & ax & 2 & 2. & 27 & & 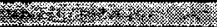 & $x$ & 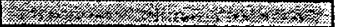 \\
\hline
\end{tabular}

detected at or above limit of detection

**Supeleo Carbotrap 300 (Carbotrap C, Carbotrap B, \& Carbosieve S-III)

***K. Foster indicated that water might be present on the thermal desorption tubes. The tube dry cycle was set to 5 minutes to remove water. GC/MS chromatograms indicted the thermal desorption tubes had been contaminated with water.

****Sample was found to contain trace amount of 1 -Butanol and Toluene,quantitation was below reportable limits of detections.

****Sample was found to contain trace amount of 1-Butanol, quantitation was below reportable limits of detections.

Please contact Marina Chiarappa at 2-2144 if you have any questions regarding this report.

ND = non-detectable 
showed that the overall carbon conversion improved to $94 \%$ and almost $100 \%$, respectively. A more detailed description of these experiments and results can be found elsewhere $[3,4]$.

Further demonstration of finer activated carbon (12 to 40 mesh) was planned in 1999 to experimentally determine whether air purge can be avoided and therefore throughput can be increased. Four different sizes of activated carbon were used for the demonstration so far. Their particle sizes, moisture contents, carbon contents, and ash contents are shown in Table 11.

Table 11: Composition of Activated Carbon for the MSO Demonstration

\begin{tabular}{lllll} 
Size, mesh & Moisture, wt\% & Ash, wt.\% & Carbon, wt.\% & \multicolumn{1}{c}{ Note } \\
$\begin{array}{l}8 \text { to } 14 \\
(1.2 \text { to } 2.4 \mathrm{~mm})\end{array}$ & 14 & 2.8 & 83.2 & $\begin{array}{l}\text { completed the run } \\
\text { in July } 1998\end{array}$ \\
$\begin{array}{l}12 \text { to } 40 \\
(0.4 \text { to } 1.4 \mathrm{~mm})\end{array}$ & 1.9 & $12.8 *$ & 85.3 & completed in $3 / 99$ \\
$\begin{array}{l}20 \text { to } 40 \\
(0.4 \text { to } 0.8 \mathrm{~mm})\end{array}$ & 4.6 & $13.1^{*}$ & 82.3 & coated with 0.5 wt.\% TNT \\
$\begin{array}{l}100 \text { mesh minus } \\
(<0.15 \mathrm{~mm})\end{array}$ & 8.1 & 1.8 & 90.1 & in water slurry
\end{tabular}

* The 12 to 40 mesh and 20 to 40 mesh carbon were made from lignite which normally contained higher content of ash.

\subsubsection{Results of Demonstration with Activated Carbon of 12 to 40 Mesh}

The vibratory solid feeder was used to deliver an average feed rate of $24.0 \mathrm{~g} / \mathrm{min}$ and 35 $\mathrm{g} / \mathrm{min}$ of 12 to 40 mesh activated carbon in late February to early March of 1999 . A total of 310 liters/min of oxidant air was fed into the vessel. This included the air sucked into the feed line through the eductor. Molten salt samples were taken before the feed, during the feed began, end of the feed, during the air purge, respectively. Furthermore, salts from the off-gas components such as salt trap and GSS filter were also collected. These salt samples were sent to C\&MS for analysis. Off-gas quality was monitored by off-gas analyzers during the course of the demonstration. Tables $12 \& 13$ show the analytical results of salts taken from the MSO vessel and off-gas components, respectively.

Table 12: Residue analysis of salt taken from the MSO vessel

\begin{tabular}{lccccc}
$\begin{array}{l}\text { Salt sample } \\
\text { conversion }\end{array}$ & $\begin{array}{c}\text { Ash content } \\
\text { In the melt }\end{array}$ & Ash* from & Carbon & Carbon in & Carbon \\
& wt.\% & $\mathrm{g}$ & $\mathrm{g}$ & $\mathrm{g}$ & $\%$ \\
\hline $\begin{array}{l}\text { During the carbon feed } \\
\text { 0 (before the feed started) }\end{array}$ & 0.01 & 16 & 0 & $\sim 0$ & \\
-- & 0.14 & 224 & 276 & $\sim 0$ & $\sim 100$
\end{tabular}


$3.5 \mathrm{hrs}$

$4.5 \mathrm{hrs}$

$0.13 \quad 208 \quad 829$

$-0$

$5.5 \mathrm{hrs}$

$0.21 \quad 336 \quad 1014$

$\sim 0$

$-100$

$6.5 \mathrm{hrs}$

0.0580

1200

$\sim 100$

(end of the carbon feed)

Air purge for $0.5 \mathrm{hrs}$

$0.21 \quad 336 \quad 1200$

Air purge for $1.5 \mathrm{hrs}$

$0.05 \quad 80 \quad 1200$

Air purge for $2.5 \mathrm{hrs}$

$0.51 \quad 816 \quad 1200$

Air purge for $3.5 \mathrm{hrs}$

$0.11 \quad 176 \quad 1200$

Air purge for $4.8 \mathrm{hrs}$

$\begin{array}{lll}0.14 & 224 \quad 1200\end{array}$

Air purge for $5.6 \mathrm{hrs}$ $0.28 \quad 448 \quad 1200$

* The ash content in the feed carbon was 12.8 wt\% per analysis by C\&MS.

Table 12 shows that all the salt sample collected contained less than $0.5 \mathrm{wt} \%$ ash, which is the typical background ash level in the molten salt. The results indicate that all carbon of finer size was destroyed quantitatively and process efficiency close to $100 \%$ has been achieved. It also shows that the extensive air purge can be avoided.

Table 13: Residue analysis of salt taken from off-gas components

\begin{tabular}{lcccc} 
& & & \multicolumn{2}{c}{ Carbon content } \\
\cline { 5 - 6 } Salt sample description & Amount of salt, g & Ash content* & wt.\% & wt.g \\
From the salt trap & 99.2 & 0 & 0.24 & 0.24
\end{tabular}

From the GSS filter $130.1 \quad 0$ $0.47 \quad 0.61$

* Ash content in the salt collected in the off-gas component is negligible.

Table 13 shows that the amount of carbon carried over to the off-gas components such as the salt trap and GSS filter were very small, less than 1.0 gram total.

Table 14 shows the off-gas compositions during the feed and air purge. The activated carbon was fed into the MSO vessel for 6.5 hours followed by a 5.6 hours of air purge.

Table 14: Off-gas analyzer readings

Off-gas Species, ppm or \% Time,

0

0.0

11.5

3.17

0.27

20.78 


\begin{tabular}{llllll}
0.5 & 0.0 & 6.39 & 37.48 & 5.50 & 15.56 \\
1.0 & 0.0 & 8.06 & 63.50 & 7.20 & 13.83 \\
1.5 & 0.0 & 9.47 & 97.56 & 8.25 & 12.82 \\
2.0 & 0.0 & 11.18 & 96.46 & 8.36 & 12.51 \\
3.0 & 0.0 & 13.77 & 101.32 & 8.62 & 12.40 \\
3.6 & 0.0 & 20.65 & 111.82 & 9.78 & 11.44 \\
4.3 & 0.0 & 15.87 & 99.49 & 9.60 & 11.23 \\
5.0 & 0.0 & 8.79 & 85.69 & 9.14 & 11.73 \\
6.5 & 0.0 & 6.10 & 74.46 & 9.13 & 11.88 \\
\hline Air Purge & & & & & \\
0 & 0.0 & 21.2 & 3.86 & 0.36 & 20.75 \\
0.75 & 0.0 & 40.4 & 3.71 & 0.24 & 20.62 \\
1.75 & 0.0 & 81.84 & 3.10 & 0.21 & 20.83 \\
3.75 & 0.0 & 113.80 & 1.66 & 0.13 & 21.06 \\
5.6 & 0.0 & 123.4 & 2.0 & 0.11 & 21.10 \\
\hline
\end{tabular}

Table 14 shows that $\mathrm{CO}_{2}$ composition increased rapidly during the 1st hour and then level off after 3 hours, an indication that the steady state was achieved in 3 to 4 hours after the carbon started. It also shows air purge for 1 hour would drop the $\mathrm{CO}_{2}$ in the off-gas to $0.2 \%$, the background for the carbonate salt at $950^{\circ} \mathrm{C}$. It was expected because almost all the carbon fed into the MSO vessel had been quantitatively oxidized before the air purge started. This indicates that an extensive air purge is not necessary with the finer activated carbon. The MSO team also demonstrated feeding of 12 to 40 mesh carbon at a higher feed rate $(35 \mathrm{~g} / \mathrm{min})$. Table 15 shows the off-gas composition during these tests.

Table 15: Off-gas analyzer readings from the run of particulate carbon at $35 \mathrm{~g} / \mathrm{min}$

Off-gas Species, ppm or \%

\begin{tabular}{clllllll} 
& \multicolumn{6}{c}{$\begin{array}{c}\text { Carbon } \\
\text { Time, hrs }\end{array}$ feed } & \multicolumn{7}{c}{ THC, ppm } & NOx,ppm & CO,ppm & $\mathrm{CO}_{2}, \%$ & $\mathrm{O}_{2}, \%$ \\
\hline 0 & $0 \mathrm{~g} / \mathrm{min}$ & 0.12 & 55.5 & 1.32 & 0.16 & 20.99 \\
0.17 & 34.0 & 0.0 & 4.20 & 61.2 & 2.76 & 16.17 \\
0.34 & 36.2 & 0.0 & 2.0 & 78.9 & 11.38 & 10.08 \\
0.67 & 35.3 & 0.0 & 9.28 & 109.1 & 12.39 & 9.04 \\
$1.1 *$ & 27.3 & 0.05 & 0.0 & 72.88 & 9.56 & 11.32 \\
\hline
\end{tabular}


* Because the amount of activated carbon in the feed hopper was not enough to keep a more stable feed rate, the feed rate dropped.

Table 15 shows that a higher carbon feed rate, approximately $35 \mathrm{~g} / \mathrm{min}(2.0 \mathrm{~kg} / \mathrm{hr})$, was achievable. Levels of $\mathrm{CO}_{2}$ in the off-gas as high as $12.4 \%$ were observed.

\subsubsection{Results of Demonstration with TNT-Loaded Carbon}

A demonstration with TNT (trinitrotoluene) -loaded carbon was conducted in April 1999 in an effort to simulate a real waste stream from a demilitarization plant. Table 16 shows the essential run conditions.

Table 16: Run Conditions for MSO Demo with TNT-loaded Carbon

No. Feeds Superficial gas velocity Run Conditions

1

$20-40$ mesh carbon $\quad 1.0 \mathrm{ft} / \mathrm{s}$ with 0.5 wt.\% TNT

$950^{\circ} \mathrm{C}, 1.4 \mathrm{~kg} / \mathrm{hr}, 30 \%$ excess air

2

20-40 mesh carbon $\quad 1.4 \mathrm{ft} / \mathrm{s}$

$950^{\circ} \mathrm{C}, 2.0 \mathrm{~kg} / \mathrm{hr}, 30 \%$ cxcess air

The same vibratory solid feeder was used to deliver an average feed rate of $1.4 \mathrm{~kg} / \mathrm{hr}$ and $2.0 \mathrm{~kg} / \mathrm{hr}$ of 20 to 40 mesh activated carbon loaded with $0.5 \mathrm{wt}$.\% TNT along with excess of oxidant air into the MSO vessel. Molten salt samples were taken before the feed, during the feed at the end of the feed, and during the air purge. Off-gas quality was monitored by off-gas analyzers during the course of the demonstration. Off-gas samples were also collected and sent for analysis of TNT. Table 17 shows the off-gas composition at steady state for runs 1 and 2 . Although a high $\mathrm{CO}$ concentration in the off-gas for run 2 was observed, it can be further reduced to the low ppm level in the catalytic converter. Both $\mathrm{NO}_{\mathrm{x}}$ and THC levels were very low, and TNT in the off-gas was less than $0.1 \mathrm{ppm}$, an indication of good process efficiency. Table 18 shows the off-gas analytical report for the runs. Analyses of the salt sample showed background levels of ash and carbon in the melt, as described in Appendix 1. This indicates that carbon was quantitatively destroyed in the MSO process vessel.

Table 17: Off-gas Composition for the MSO Demo with TNT-loaded Carbon

\begin{tabular}{ccc} 
& \multicolumn{2}{c}{ Run Numbers } \\
\cline { 2 - 3 } Off-gas Species & 1 & 2 \\
\hline $\mathrm{CO}_{2}, \%$ & 11.8 & 15.8 \\
$\mathrm{O}_{2}, \%$ & 9.3 & 5.8 \\
$\mathrm{CO}, \mathrm{ppm}$ & 36.1 & 340 \\
$\mathrm{NO}_{\mathrm{x}}, \mathrm{ppm}$ & 6.8 & 19.0 \\
$\mathrm{THC}, \mathrm{ppm}$ & 0.09 & $0.0 *$ \\
\hline
\end{tabular}

*The off-gas analyzers drifted down during the course of the run. 
ANALYTICAL INFORMATION

\begin{tabular}{|c|c|c|c|c|c|c|c|c|c|}
\hline 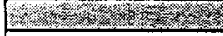 & 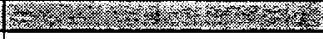 & 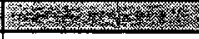 & 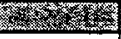 & 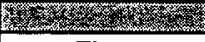 & 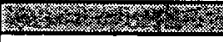 & W & 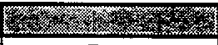 & X) & - \\
\hline Lab Log \# & $\begin{array}{c}\text { Sample } \\
\text { Identification }\end{array}$ & $\begin{array}{c}\mathrm{COC} \\
*\end{array}$ & Sampler & $\begin{array}{l}\text { Time } \\
\text { Sampled }\end{array}$ & $\begin{array}{c}\text { Date } \\
\text { Sampled }\end{array}$ & $\begin{array}{c}\text { Date } \\
\text { Recelved }\end{array}$ & $\begin{array}{c}\text { Date } \\
\text { Analyzed }\end{array}$ & Analyst & $\begin{array}{c}\text { Detection } \\
\text { Linits } \mu g / \mathrm{L}\end{array}$ \\
\hline 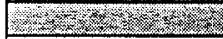 & 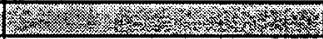 & 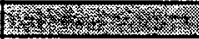 & 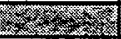 & 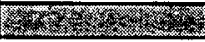 & 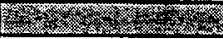 & 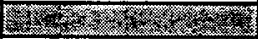 & r6\% & stror & 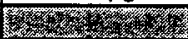 \\
\hline EC99004-0004 & MS-16 & N/A & $\mathbf{K r}$ & N/A & 4869 & $4 / 2299$ & 412199 & $\mathbf{K C}$ & $25 \mathrm{ng}$ \\
\hline EC99004-0005 & MS-17 & $\mathrm{N} / \mathrm{A}$ & $\mathbf{K F}$ & $\mathrm{N} / \mathrm{A}$ & 4899 & $4 / 1299$ & $4 / 12199$ & $\mathbf{K C}$ & $25 \mathrm{ng}$ \\
\hline EC9900400066 & MS-18 & $\mathbf{N} / \mathbf{A}$ & $\mathbf{K F}$ & $\mathrm{N} / \mathrm{A}$ & 4899 & 412299 & $4 / 12199$ & $\mathbf{K C}$ & $25 \mathrm{ng}$ \\
\hline EC99004-0007 & MS-19 & $\mathrm{N} / \mathrm{A}$ & $\mathbf{K} \mathbf{F}$ & $\mathrm{N} / \mathrm{A}$ & 4899 & $4 / 12199$ & $4 / 2299$ & $\mathbf{K C}$ & $25 \mathrm{ng}$ \\
\hline EC99004-0008 & MS-13 & N/A & $\mathbf{K F}$ & $\mathrm{N} / \mathrm{A}$ & 4989 & $4 / 1299$ & 4/138999 & $\mathbf{K C}$ & $25 \mathrm{nz}$ \\
\hline EC99004-0009 & MS-14 & $\mathrm{N} / \mathrm{A}$ & $\mathbf{K F}$ & N/A & 4999 & 4/1209 & $4 / 3399$ & $\mathbf{K C}$ & $23 \mathrm{ng}$ \\
\hline EC99004-0010 & MS-15 & $\mathrm{N} / \mathrm{A}$ & $\mathbf{K T}$ & $\mathbf{N} / \mathbf{A}$ & 4909 & $4 / 299$ & $4 / 3199$ & $\mathbf{K C}$ & $25 \mathrm{nz}$ \\
\hline
\end{tabular}

ANALYTICAL RESULTS

\begin{tabular}{|c|c|c|c|c|c|c|c|c|c|c|c|}
\hline 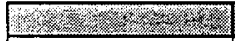 & 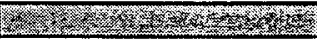 & 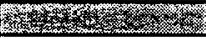 & 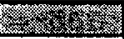 & Sy & 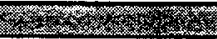 & 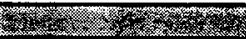 & 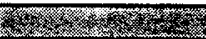 & 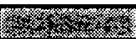 & $4 x+2 y-x$ & 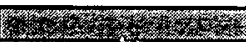 & 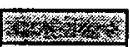 \\
\hline Lab Log * & $\begin{array}{c}\text { Sample } \\
\text { Identification }\end{array}$ & \begin{tabular}{|c|} 
Dichloroethylene \\
ng
\end{tabular} & $\begin{array}{c}\text { Freon } 113 \\
\mathrm{ng}\end{array}$ & \begin{tabular}{|c|} 
Tetrachloroethune \\
ng
\end{tabular} & $\begin{array}{c}\text { Trichloroethylene } \\
\text { ng }\end{array}$ & $\begin{array}{c}\text { 1,1,1-Trichloroethane } \\
\text { ng }\end{array}$ & $\begin{array}{c}\text { Furans } \\
\text { ng }\end{array}$ & $\begin{array}{c}\text { Dioxanes } \\
\text { ng }\end{array}$ & $\begin{array}{l}\text { Tolvene } \\
\text { ng }\end{array}$ & $\begin{array}{c}\text { 2,4,6-Trinitrotoluene } \\
\text { ng }\end{array}$ & $\begin{array}{c}\text { Acetone } \\
\text { ng }\end{array}$ \\
\hline 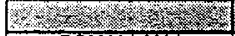 & 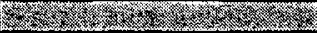 & 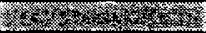 & 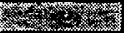 & $148 \%$ & 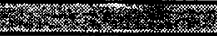 & 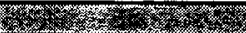 & & & (6) & & \\
\hline EC99004-0004 & MS-16 & ND* & ND & ND & ND*t* & ND & ND & ND & ND & ND & ND \\
\hline EC99004-0005 & MS.17 & ND & ND & $\mathrm{ND***}$ & ND & ND & ND & ND & ND & ND & ND \\
\hline EC99004-0006 & MS-18 & ND & ND & ND & ND & $\mathrm{ND}$ & ND & ND & ND & ND & ND \\
\hline EC99 & MS-19 & ND & ND & ND & No & ND & ND & ND & $\mathrm{ND}$ & ND & ND \\
\hline EC990 & MS.13 & ND & ND & ND & ND & ND & ND & $\mathrm{NI}$ & ND & ND & $\overline{\mathrm{ND}}$ \\
\hline EC 990040009 & MS-14 & ND & NI & ND & $\mathbf{N}$ & ND & ND & ND & ND & ND & ND \\
\hline EC99004-0010 & MS-15 & ND & ND & ND & ND & ND & ND & ND & ND***4 & ND & ND \\
\hline 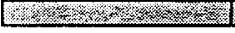 & 27 & 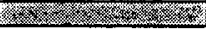 & & 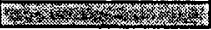 & 10 & & & & & & \\
\hline
\end{tabular}

$\mathrm{ND}=\mathrm{Not}$ detected at or above limit of detection

-"Supeleo Cartotrap 300 (Carbotrap C, Carbotrap B, \& Carbosieve S-III)

-..Trace amount found bur below reportable detection limit

Please contact Marina Chiarappa at 2-2144 if you have any questions regarding this report.

$\mathrm{ND}=$ non-detectable 


\subsubsection{Results of Demonstration with Carbon Slurry}

A demonstration with carbon slurry was conducted in April 1999. The purpose of the carbon slurry testing was to determine the efficacy of MSO technology for treating carbon sludge generated in industry and the demilitarization complex. The slurry consisted of carbon (100 mesh and finer) and water. It was pumpable at $20 \mathrm{wt} \%$ carbon loading. Higher carbon loading was not attenuated because of schedule and funding limitations. Table 19 shows the run conditions.

Table 19: Run Conditions for MSO Demo with Carbon Slurry

\begin{tabular}{lll} 
No. & \multicolumn{1}{c}{ Feeds } & Run Conditions \\
\hline 1 & 100 mesh minus & \\
& 15 wt. \% C, 85\% H2O & $950^{\circ} \mathrm{C}, 3.3 \mathrm{~kg} / \mathrm{hr}$, excess air \\
2 & 100 mesh minus & \\
& 20 wt. $\%$ C, $80 \% \mathrm{H} 2 \mathrm{O}$ & $950^{\circ} \mathrm{C}, 3.3 \mathrm{~kg} / \mathrm{hr}$, excess air
\end{tabular}

The carbon slurry was pumped into the MSO vessel with an excess of oxidant air. The salt temperature was controlled at $950^{\circ} \mathrm{C}$ and the off-gas composition was monitored by off-gas analyzers during the course of the demonstration. Table 20 shows the off-gas composition at steady state for runs 1 and 2 . The off-gas quality was observed to be excellent, and the results show that the carbon slurry/sludge can be effectively treated using the MSO process.

Table 20: Off-gas Composition for the MSO Demo with Carbon Slurry Feed

\begin{tabular}{ccc} 
& \multicolumn{2}{c}{ Run Numbers } \\
\cline { 2 - 3 } Off-gás Species & 1 & 2 \\
\hline $\mathrm{CO}_{2}, \%$ & 7.9 & 9.3 \\
$\mathrm{O}_{2}, \%$ & 13.4 & 12.2 \\
$\mathrm{CO}, \mathrm{ppm}$ & 8.2 & 6.8 \\
$\mathrm{NO}_{\mathrm{x}}, \mathrm{ppm}$ & 3.3 & 3.0 \\
$\mathrm{THC}, \mathrm{ppm}$ & 0.2 & 0.04 \\
\hline
\end{tabular}

\section{EXPERIMENTS IN THE SALT RECYCLE SYSTEM AND RESULTS}

\subsection{Salt Recycle Experiments}

The salt recycle system processes spent salts generated in MSO. If the spent salts contain significant levels of carbonate, the system will spray-dry the resulting clean salt solution and send the dried salt back to the MSO vessel in order to minimize the generation of secondary waste as well as to reduce cost. If the spent salts contain very high levels of chloride and are destined for disposal, the SR system can clean up the salts and remove contaminants to a degree which meets the specification acceptable for final disposal. In FY99, there were three batches of spent salts processed in the salt recycle system, SR7, 
SR8, and SR9. Processing of each spent salt followed the procedure described elsewhere $[1,2]$ and summarized in Fig. 4. A detailed description of the salt recycle operational procedure can be found in the operational manual [5].

SR7 was the spent salt drained from MSO after demonstration with the ion exchange resin slurry. This salt was also used for MSO demonstration with uranyl nitrate-spiked dichlorophenol containing organic in September 1998 as part of FY98 activities. It was a high carbonate spent salt with low concentration of chloride and sulfate. Traces of metal compounds such as chromium, nickel and iron are also expected in the salt. SR8 is the spent salt drained from MSO after the FY99 treatability studies. SR9 was spent salts drained after the carbon testing and treatment of residual waste organics, $50 \mathrm{~kg}$ total, which was accumulated through the duration of the MSO operation since December 1997.

In the salt recycle experiments, the salt solutions and the resulting solid salts were routinely analyzed for a variety of metals using ICP-OES. Additional analyses were occasionally performed for anionic species such as $\mathrm{Cl}, \mathrm{F}, \mathrm{NO}_{3}^{-}, \mathrm{SO}_{4}{ }^{2-}, \mathrm{CO}_{3}{ }^{2-}$, and $\mathrm{PO}_{4}^{3-}$ using ion chromatography, and uranium concentrations were determined by using ICP-MS.

\subsection{Results of the Demonstration of the Salt Recycle System}

Salt recycle is an important element of the intcgrated MSO system. It was developed based on extensive small-scale laboratory experiments to prove the concept with subsequent scalc-up to the pilot system as part of an integrated MSO facility. The salt recycle proccss separates metals, mineral residues, and radionuclides from spent salt generated by the MSO process. It includes salt size reduction with a grinder, salt dissolution in water, precipitation, chemical reduction, filtration, $\mathrm{pH}$ adjustments, ion exchange, and drying. Each component in the salt recycle system was shown to work as designed.

The salt recycle system has successfully treated six batches of spent salt generated from the MSO vessel in FY98 [1]. In FY99, three batches of spent salt (SR7, SR8, SR9) were treated. Tables 21,22 , and 23 list the compositions of starting salt, filtered untreated salt solution, and filtered treated solution for SR7, SR8, and SR9, respectively. These salt batches consisted of mostly sodium carbonate with traces of sodium chloride, sodium floride, sodium phosphate, sodium sulfate along with some metals such as nickel and chromium. Table 22 also shows the composition of SR8 slurry which was from the decaking operation of the filter in the salt recycle system. The high levels of $\mathrm{Al}$ and $\mathrm{SiO} 2$ came from wastes fed into the MSO vessel and from the filter aids (aluminum hydroxide and diatomaceous earth) used for the filter precoating. It also shows that the slurry contained high levels of chromium and nickel along with several other metals.

Table 24 shows the cation concentrations in the salt before and after the salt recycle for SR7, SR8, and SR9. The presence of chromium and nickel in the spent salt was expected because the vessel was made of Inconel 600 which contains chromium and nickel as major components. The table shows that all the nickel was removed and more than $90 \%$ of chromium in the spent salt was removed in the salt recycle system, resulting in clean salt solution with ppm levels of chromium. It was difficult to remove all the chromium in the carbonate salt solution due to the solubility of both $\mathrm{Cr}+3$ and $\mathrm{Cr}+6$ in the solution.

\section{MSO VESSEL WALL THICKNESS}

The MSO vessel with a 0.5 inches thick wall was designed to operate for at least 10,000 hours of continuous operation at temperature above $900^{\circ} \mathrm{C}$. Since May of 1997, the vessel has been inspected three times and is due up for inspection in early June 1999. The vessel 


\section{Figure 4 Flowsheet for Aqueous Processing of Spent Salt}

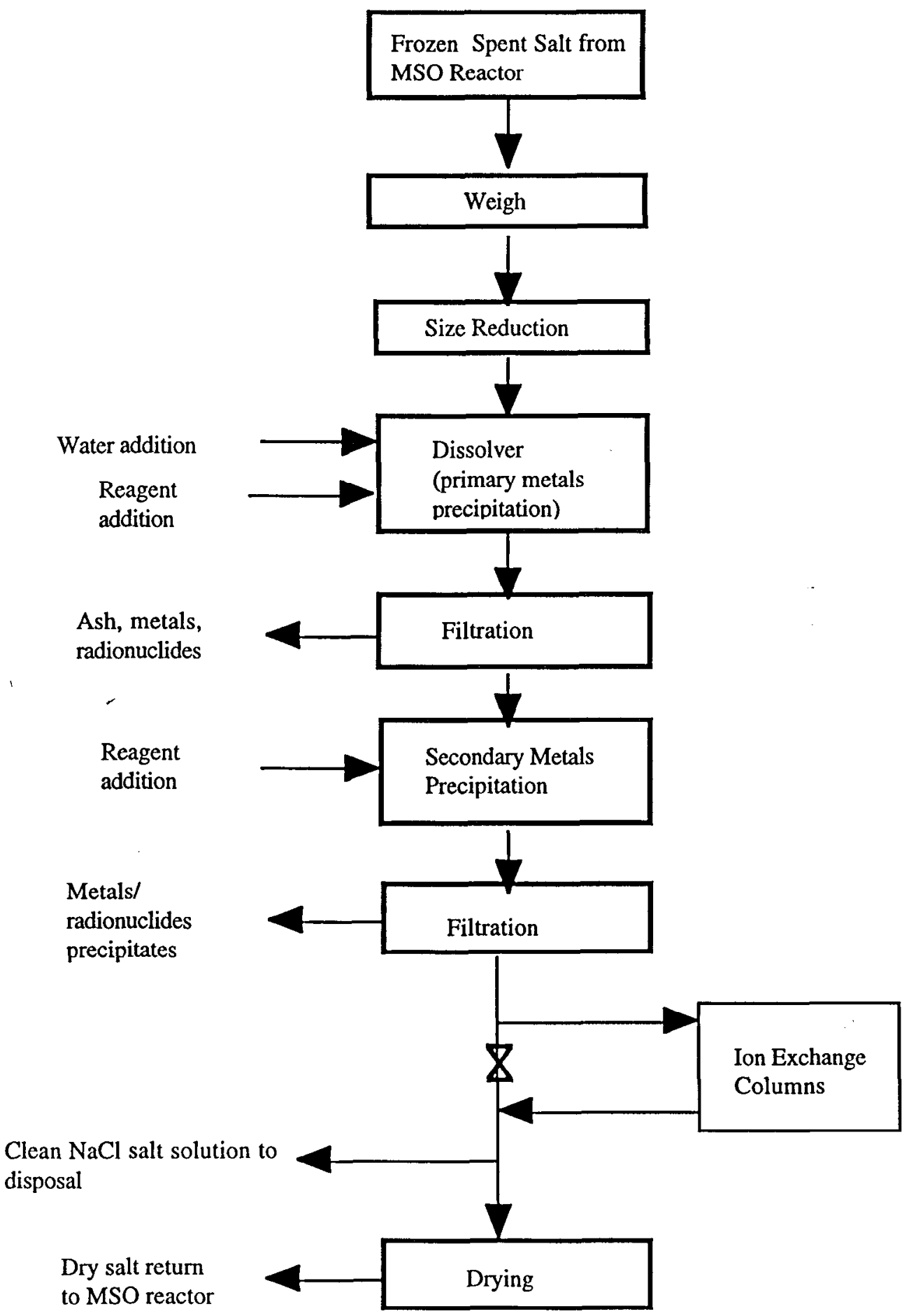


Table 21: Salt Recycle System Analytical Work for SR7

\begin{tabular}{|c|c|c|c|}
\hline $\begin{array}{l}\text { Analysis performed } \\
\text { by }\end{array}$ & $\begin{array}{l}\text { Starting } \\
\text { Spent salt } \\
\text { C\&MS }\end{array}$ & $\begin{array}{c}\text { Filtered } \\
\text { Untreated } \\
\text { Solution } \\
\text { C\&MS }\end{array}$ & $\begin{array}{c}\text { Filtered Treated } \\
\text { Solution } \\
\text { C\&MS }\end{array}$ \\
\hline $\begin{array}{l}\text { Samples given on } \\
\text { TDS, g/ml solution }\end{array}$ & $\begin{array}{l}12 / 9 / 98 \\
\text { N/A }\end{array}$ & $\begin{array}{l}12 / 9 / 98 \\
0.228\end{array}$ & $\begin{array}{c}12 / 18 / 98 \\
0.191\end{array}$ \\
\hline $\begin{array}{c}\text { Cations } \\
\mathrm{Ag} \\
\mathrm{As} \\
\mathrm{Ba} \\
\mathrm{Be} \\
\mathrm{Cd} \\
\mathrm{Co} \\
\mathrm{Cr} \\
\mathrm{Cu} \\
\mathrm{Mo} \\
\mathrm{Hg} \\
\mathrm{Ni} \\
\mathrm{Pb} \\
\mathrm{Sb} \\
\mathrm{Se} \\
\mathrm{Tl} \\
\mathrm{V} \\
\mathrm{Zn}\end{array}$ & $\begin{array}{l}\text { ND } \\
\text { ND } \\
\text { ND } \\
\text { ND } \\
\text { ND } \\
\text { ND } \\
370 \\
\text { ND } \\
\text { ND } \\
\text { ND } \\
460 \\
\text { ND } \\
\text { ND } \\
\text { ND } \\
\text { ND } \\
\text { ND } \\
\text { ND }\end{array}$ & $\begin{array}{l}\text { ND } \\
\text { ND } \\
\text { ND } \\
\text { ND } \\
\text { ND } \\
\text { ND } \\
120 \\
\text { ND } \\
\text { ND } \\
\text { ND } \\
\text { ND } \\
\text { ND } \\
\text { ND } \\
\text { ND } \\
\text { ND } \\
\text { ND } \\
\text { ND }\end{array}$ & $\begin{array}{l}\text { ND } \\
\text { ND } \\
\text { ND } \\
\text { ND } \\
\text { ND } \\
\text { ND } \\
2 \\
\text { ND } \\
\text { ND } \\
\text { ND } \\
\text { ND } \\
\text { ND } \\
\text { ND } \\
\text { ND } \\
\text { ND } \\
\text { ND } \\
\text { ND }\end{array}$ \\
\hline $\begin{array}{l}\mathrm{U} \\
\mathrm{Al} \\
\mathrm{Na}\end{array}$ & 420000 & $\begin{array}{c}74 \\
95000\end{array}$ & $\begin{array}{c}70 \\
80000\end{array}$ \\
\hline \multicolumn{4}{|l|}{ Anions } \\
\hline $\begin{array}{c}\text { F- } \\
\text { Cl- } \\
\text { Br- } \\
\text { NO3- } \\
\text { PO4-3 } \\
\text { SO4-2 } \\
\text { Carbonate }\end{array}$ & $\begin{array}{c}<7 \\
6570 \\
<30 \\
<20 \\
<70 \\
1430 \\
\text { Balance }\end{array}$ & $\begin{array}{c}<7 \\
1820 \\
<30 \\
<20 \\
<70 \\
229 \\
\text { Balance }\end{array}$ & $\begin{array}{c}<7 \\
57 \\
<30 \\
<20 \\
<70 \\
<20 \\
\text { Balance }\end{array}$ \\
\hline tab & & & \\
\hline
\end{tabular}


Table 22: Salt Recycle System Analytical Work for SR8

$\begin{array}{ccccc} & \begin{array}{c}\text { Starting } \\ \text { Spent Salt * } \\ \text { C\&MS }\end{array} & \begin{array}{c}\text { Filtered } \\ \text { Untreated } \\ \text { Solution } \\ \text { C\&MS }\end{array} & \begin{array}{c}\text { Filtered } \\ \text { Treated } \\ \text { Solution } \\ \text { C\&MS }\end{array} & \begin{array}{c}\text { Slurry } \\ \text { C\&MS }\end{array} \\ \begin{array}{c}\text { Analysis performed } \\ \text { by }\end{array} & \text { N/A } & 0.180 & 0.180 & 0.208\end{array}$

\section{Cations}

\begin{tabular}{|c|c|c|c|}
\hline $\mathrm{Ag}$ & ND & ND & ND \\
\hline As & ND & ND & ND \\
\hline $\mathrm{Ba}$ & ND & ND & 150 \\
\hline $\mathrm{Be}$ & 0.3 & ND & 80 \\
\hline $\mathrm{Cd}$ & ND & ND & 89 \\
\hline Co & ND & ND & 110 \\
\hline $\mathrm{Cr}$ & 230 & 2 & 44000 \\
\hline $\mathrm{Cu}$ & ND & ND & 180 \\
\hline Mo & ND & $\mathrm{ND}$ & ND \\
\hline $\mathrm{Hg}$ & ND & ND & ND \\
\hline $\mathrm{Ni}$ & ND & ND & 93000 \\
\hline $\mathrm{Pb}$ & ND & ND & 200 \\
\hline $\mathrm{Sb}$ & ND & ND & ND \\
\hline $\mathrm{Se}$ & ND & ND & ND \\
\hline T1 & $\mathrm{ND}$ & ND & ND \\
\hline $\mathrm{V}$ & $\mathrm{ND}$ & ND & ND \\
\hline $\mathrm{Zn}$ & ND & ND & 630 \\
\hline Ư & 2 & 1.9 & \\
\hline $\mathrm{Al}$ & ND & 61 & 160000 \\
\hline $\mathrm{Na}$ & 83000 & 82000 & 22000 \\
\hline $\mathrm{SiO} 2$ & & & 579300 \\
\hline \multicolumn{4}{|l|}{ Anions } \\
\hline F- & 474 & 488 & 28 \\
\hline Cl- & 29200 & 30200 & 2220 \\
\hline $\mathrm{Br}-$ & $<4$ & $<4$ & $<7$ \\
\hline NO3- & 12 & 12.7 & 19 \\
\hline PO4-3 & $<5$ & 2340 & $<10$ \\
\hline SO4-2 & 137 & 1770 & 1030 \\
\hline Carbonat & Balance & Balance & \\
\hline
\end{tabular}

*Due to a sampling error, the starting spent salt was not collected and analyzed.

$\mathrm{ND}=$ Non-detectable 
Table 23: Salt Recycle Systen Analytical Work for SR9

\begin{tabular}{|c|c|c|c|}
\hline Analysis performed & $\begin{array}{l}\text { Starting } \\
\text { spent salt } \\
\text { C\&MS }\end{array}$ & $\begin{array}{c}\text { Filtered } \\
\text { Untreated } \\
\text { Solution } \\
\text { C\&MS }\end{array}$ & $\begin{array}{l}\text { Filtered Treated } \\
\text { Solution } \\
\text { C\&MS }\end{array}$ \\
\hline $\begin{array}{l}\text { by } \\
\text { Tamples given on } \\
\text { TDS, g/ml solution }\end{array}$ & $\begin{array}{c}12 / 9 / 98 \\
\text { N/A }\end{array}$ & $\begin{array}{c}12 / 9 / 98 \\
0.172\end{array}$ & $\begin{array}{c}12 / 18 / 98 \\
0.176\end{array}$ \\
\hline $\begin{array}{c}\text { Cations } \\
\mathrm{Ag} \\
\mathrm{As} \\
\mathrm{Ba} \\
\mathrm{Be} \\
\mathrm{Cd} \\
\mathrm{Co} \\
\mathrm{Cr} \\
\mathrm{Cu} \\
\mathrm{Mo} \\
\mathrm{Hg} \\
\mathrm{Ni} \\
\mathrm{Pb} \\
\mathrm{Sb} \\
\mathrm{Se} \\
\mathrm{Tl} \\
\mathrm{V} \\
\mathrm{Zn}\end{array}$ & $\begin{array}{c}\text { ND } \\
\text { ND } \\
70 \\
\text { ND } \\
\text { ND } \\
\text { ND } \\
1730 \\
10.5 \\
17.5 \\
\text { ND } \\
1280 \\
\text { ND } \\
\text { ND } \\
\text { ND } \\
\text { ND } \\
6.7 \\
5.2\end{array}$ & $\begin{array}{c}\text { ND } \\
\text { ND } \\
0.4 \\
\text { ND } \\
\text { ND } \\
\text { ND } \\
293 \\
0.2 \\
3.0 \\
\text { ND } \\
\text { ND } \\
\text { ND } \\
\text { ND } \\
\text { ND } \\
\text { ND } \\
1.1 \\
0.08 D\end{array}$ & $\begin{array}{l}\text { ND } \\
\text { ND } \\
0.05 \\
\text { ND } \\
\text { ND } \\
\text { ND } \\
8.5 \\
\text { ND } \\
3.0 \\
\text { ND } \\
\text { ND } \\
\text { ND } \\
\text { ND } \\
\text { ND } \\
\text { ND } \\
1.0 \\
0.06\end{array}$ \\
\hline $\begin{array}{c}\mathrm{U} \\
\mathrm{Al} \\
\mathrm{Na} \\
\mathrm{K} \\
\text { Anions }\end{array}$ & $\begin{array}{c}672 \\
414,000 \\
172,000\end{array}$ & $\begin{array}{c}57 \\
70,700 \\
29,400\end{array}$ & $\begin{array}{c}40 \\
71,700 \\
29,700\end{array}$ \\
\hline $\begin{array}{c}\text { F- } \\
\text { Cl- } \\
\text { Br- } \\
\text { NO3- } \\
\text { PO4-3 } \\
\text { SO4-2 } \\
\text { Carbonate }\end{array}$ & $\begin{array}{c}183 \\
5980 \\
<30 \\
781 \\
1280 \\
6090 \\
\text { Balance }\end{array}$ & $\begin{array}{c}71 \\
1690 \\
<3 \\
88 \\
273 \\
1740 \\
\text { Balance }\end{array}$ & $\begin{array}{c}39 \\
1670 \\
<3 \\
83 \\
199 \\
2810 \\
\text { Balance }\end{array}$ \\
\hline & & & \\
\hline
\end{tabular}




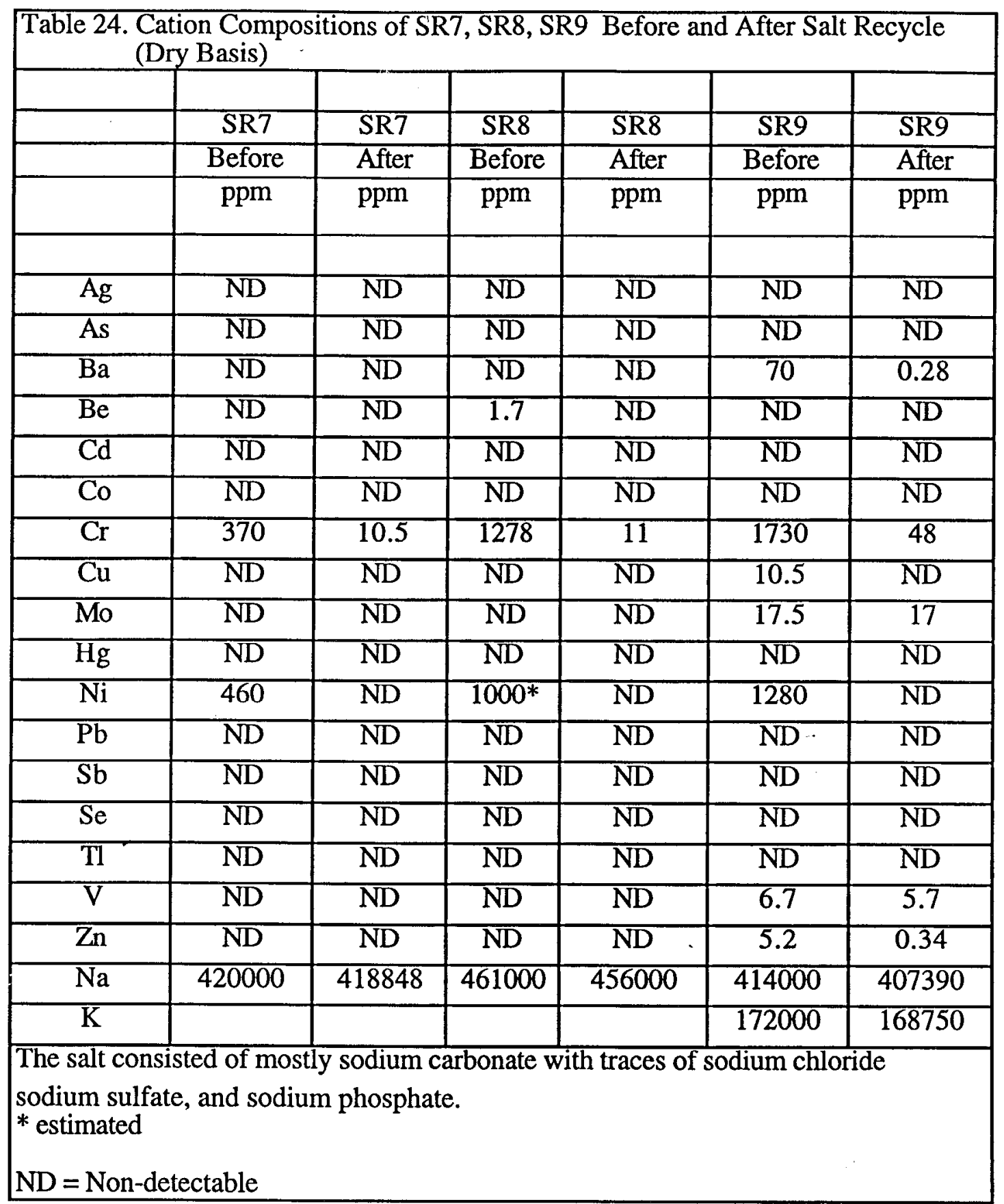


was inspected with an ultrasonic meter at various locations along the vessel wall. Results of the inspection are shown in Table 25.

Table 25: MSO Vessel Inspection Results

\begin{tabular}{lcccc} 
Time & $\begin{array}{c}\text { Vessel wall thickness } \\
\text { Inches }\end{array}$ & $\begin{array}{c}\text { Hours of } \\
\text { operation }\end{array}$ & $\begin{array}{c}\text { Corrosion rate } \\
\text { inches/100 hrs }\end{array}$ & Note \\
\hline May, 1997 & 0.500 & 0 & N/A & New Vessel \\
March, 1998 & 0.496 & 150 & 0.0027 & \\
November, 1998 & 0.492 & 750 & 0.0011 & \\
June, 1999 & & over 1000 & & due up next month \\
\hline
\end{tabular}

Table 25 shows that the corrosion rate was only 0.0027 inches per 100 hours of operation at temperature above $900^{\circ} \mathrm{C}$ in the beginning and that it later dropped to 0.001 inches $/ 100$ hrs. The reduction in corrosion rate was probably due to the formation of a protective layer on the inner wall of the MSO vessel. At this corrosion rate, a MSO vessel with a $1 / 2$ inch thick wall would be able to operate for 25000 hours. For a MSO treatment plant operating 5000 hours a year, the MSO vessel would last for approximately 5 years before a replacement vessel is needed.

\section{CONCLUSION}

An integrated MSO pilot-scale facility has been built and demonstrations conducted since December 1997. The facility has been demonstrated with over 30 different feeds, including surrogates and real waste streams, liquid and solid. Results of the demonstrations covering activities from December 1997 to September 1998 are available elsewhere [1,2,4,6,7].

For ion exchange resins, higher levels of $\mathrm{NO}_{\mathrm{x}}, \mathrm{CO}$, and THC in the off-gas system were observed occasionally during the experiments. These NOx, CO and THC concentrations can be reduced in the catalytic converter before venting to the facility stack. The system has been demonstrated with a gas superficial velocity up to $1.5 \mathrm{ft} / \mathrm{s}$ with good results. As high as $7.8 \mathrm{~kg} / \mathrm{hr}$ of chlorinated solvent (RTS\#4, a real waste specimen) was fed into the MSO vessel and successfully treated. For activated carbon sized 12 to 40 mesh and smaller, it appears that an extensive air purge is not needed. This would allow the owner of a MSO plant to operate the system efficiently with this type of feed. Carbon feed rates as high as 2 $\mathrm{kg} / \mathrm{hr}$ are possible using the existing pilot plant.

For a variety of organic-based wastes, MSO is technically mature and is ready to be fielded and implemented at DOE sites, DOD installations, and in some commercial applications. 
Acknowledgments

The authors wish to thank the following people who contributed to this work: Gregg Soto, David Hipple, Ken Foster, Tim Ford, Gary Work and Dwight Squire. Special thanks to Samuel Brinker of DOE/Oakland Operations for his guidance and support. This work was performed under the auspices of the U.S. Department of Energy by the Lawrence Livermore National Laboratory under contract number W-7405-ENG-48. Funding was provided by DOE/EM's Office of Waste Management (EM-30), and Mr. James Q. Wheeler, Director, Defense Ammunition Center, McAlester, OK.

\section{References}

1. Peter C. Hsu, Martyn G. Adamson, David L. Hipple, and Robert W. Hopper, "FY98 Final Report for the Expedited Technology Demonstration Project: Demonstration Test Results for the Integrated MSO Waste Treatment System," Lawrence Livermore National Laboratory , March 1999

2. Peter C. Hsu, David Hipple, Dwight Squire, Erica von Holtz, Robert Hopper, and Martyn Adamson, "Integrated Demonstration of Molten Salt Oxidation with Salt Recycle for Mixed Waste Treatment," UCRL-JC-128143, Proceedings of Waste Management ‘98, Tucson, AZ, March 1998.

3. Peter C. Hsu and Martyn G. Adamson, "Treatment of Activated Carbon with Molten Salt Oxidation," unpublished report, LLNL, September 1988.

4. Peter C. Hsu, Ken Foster, Tim Ford, Henrik Wallman, Bruce Watkins, César Pruneda, and Martyn Adamson, "Treatment of Solid Wastes with Molten Salt Oxidation," UCRL-JC-132670, Proceedings of International Conference on Incineration and Thermal Treatment Technology, Orlando, FL, May 1999

5. Peter C. Hsu, David H. Hipple, and Martyn Adamson, "MSO Salt Recycle System Operation Manual," Lawrence Livermore National Laboratory, 1998.

6. Martyn Adamson, Peter C. Hsu, David Hipple, Ken Foster, Robert Hopper, and Tim Ford, "Organic Waste Processing using Molten Salt Oxidation," UCRL-JC-129946, presented at 1998 Euchem Conference on Molten Salt Oxidation, France, June 1998.

7. Peter C. Hsu, David Hipple , Ken Foster, Tim Ford, and Martyn Adamson, "Molten Salt Oxidation For Trcating Low-level Mixed Wastes," UCRL-JC-131718, Proceedings of the Waste Management '99 Conference, Tucson, AZ, March 4, 1999. 
Appendix 1

Interdepartmental letterhead

CHEMISTRY \& MATERIALS SCIENCE DEPT.

Mail Station L-310

Analytical Sciences Div.

Ext: 26414

May 10, 1999

To: $\quad$ Dave Silberman/P. Hsu

From: Nora Briant

Regarding: Total Ash and Carbon Determination of Molten Salt Samples

Purpose of Analysis

The purpose of the analysis was to determine the total ash content and carbon content of molten salt samples

\section{Method}

\section{Total Ash}

Total ash was determined by weighing $\sim 5$ grams of sample into a $200-\mathrm{ml}$ plastic beaker. Approximately $100 \mathrm{ml}$ of water were added to dissolve carbonate. $5-\mathrm{ml}$ of $\mathrm{HCl}$ and $10-\mathrm{ml}$ of $\mathrm{HNO} 3$ was mixed together and added slowly to the sample while stirring with a magnetic stirring bar. The samples were left to sit over the weekend. Samples were filtered through tared nuclepore carbonate membrane filters. The filters were place in tared glass bottles and dried at 110 degrees $C$ for four hours. The samples were removed from the oven, placed in a dessicator and allowed to cool to room temperature. The samples were weighed. The total ash was then calculated by subtracting the tare weights.

\section{Carbon}

Samples were prepared the same as for total ash up to the point of adding the $\mathrm{HCl}$ and $\mathrm{HNO} 3$ and allowing the samples to sit overnight. The aqueous acid was carefully aspirated from each sample to a minimum volume being careful not to aspirate any of the solid residue. $10-\mathrm{ml}$ of $\mathrm{HF}$ was then added to residue. Samples were then left to sit over the weekend. Boric acid ( 4 4rams) and 100-ml of water was added to each sample. The samples were sonicated to dissolve the boric acid. Samples were left to sit overnight. Samples were filtered, dried and weighed as previously described for the total ash determination. 


\section{Results}

The results were calculated as total ash and total carbon and as weight percent of each. In the carbon determination all of the samples except TNT/C-SS-11 contained brown residue in addition to black carbon residue. It is suspected that brown residue that remains is some sort of refractory material and not carbon. The reported carbon results are the total of this brown residue plus any carbon present. The results are attached. The total ash results are reported in table \#1 and the carbon results in table \#2 


\section{Appendix 1b}

\begin{tabular}{clll} 
To: & Dave Silberman & ASRS Case \#: & 1249 \\
From: & Nora Briant & Account: & $6724-12$ \\
Analysis Date: & $4 / 22-5 / 7 / 99$ & Report Dàte: & $5 / 10 / 99$ \\
\hline
\end{tabular}

Table\#1 Total Ash Content

\begin{tabular}{|l|l|l|c|c|c|c|c|}
\hline TC\# & $\begin{array}{c}\text { Requester's } \\
\text { ID }\end{array}$ & $\begin{array}{c}\text { Sample } \\
\text { weight } \\
\text { grams }\end{array}$ & $\begin{array}{c}\text { filter } \\
\text { tare } \\
\text { grams }\end{array}$ & $\begin{array}{c}\text { Bottle } \\
\text { tare } \\
\text { grams }\end{array}$ & $\begin{array}{c}\text { Bottle, filter } \\
\text { Ash } \\
\text { grams }\end{array}$ & $\begin{array}{c}\text { Total } \\
\text { Ash } \\
\text { grams }\end{array}$ & $\begin{array}{c}\text { Weight \% } \\
\text { Ash }\end{array}$ \\
\hline 990041 & TNT/C-SS-5 & 5.0351 & 0.0139 & 51.5182 & 51.5473 & 0.0152 & 0.302 \\
\hline 990042 & TNT/C-SS-2 & 5.0167 & 0.0142 & 51.0250 & 51.0590 & 0.0198 & 0.395 \\
\hline 990043 & TNT/C-SS-3 & 5.7110 & 0.0146 & 51.4382 & 51.4981 & 0.0453 & 0.793 \\
\hline 990044 & TNT/C-SS-4 & 5.1972 & 0.0146 & 51.9372 & 51.9678 & 0.0160 & 0.308 \\
\hline 990045 & TNT/C-SS-6 & 5.1473 & 0.0148 & 51.5665 & 51.5965 & $\mathbf{0 . 0 1 5 2}$ & 0.295 \\
\hline 990046 & TNT/C-SS-7 & 5.3015 & 0.0155 & 51.4565 & 51.4882 & 0.0162 & 0.306 \\
\hline 990047 & TNT/C-SS-8 & 5.1330 & 0.0158 & 51.4227 & 51.4498 & 0.0113 & 0.220 \\
\hline 990048 & TNT/C-SS-9 & 5.0110 & 0.0159 & 51.2127 & 51.2558 & 0.0272 & 0.543 \\
\hline 990049 & TNT/C-SS-10 & 5.4443 & 0.0152 & 51.8050 & 51.8294 & 0.0092 & 0.169 \\
\hline 990050 & TNT/C-SS-11 & 5.1493 & 0.0154 & 51.4667 & 51.4873 & 0.0052 & 0.101 \\
\hline 990051 & TNT/C-SS-1 & 5.0289 & 0.0155 & 52.2536 & 52.2973 & 0.0282 & 0.561 \\
\hline
\end{tabular}

Table \#2 Carbon Content

\begin{tabular}{|l|l|c|c|c|c|c|c|}
\hline TC\# & \multicolumn{1}{|c|}{$\begin{array}{c}\text { Requester's } \\
\text { ID }\end{array}$} & $\begin{array}{c}\text { Sample } \\
\text { weight } \\
\text { grams }\end{array}$ & $\begin{array}{c}\text { filter } \\
\text { tare } \\
\text { grams }\end{array}$ & $\begin{array}{c}\text { Bottle } \\
\text { tare } \\
\text { grams }\end{array}$ & $\begin{array}{c}\text { Bottle, filter } \\
\text { Carbon } \\
\text { grams }\end{array}$ & $\begin{array}{c}\text { Total } \\
\text { Carbon } \\
\text { grams }\end{array}$ & $\begin{array}{c}\text { Weight \% } \\
\text { Carbon }\end{array}$ \\
\hline 990041 & TNT/C-SS-5 & 11.7400 & 0.0155 & 51.6519 & 51.6875 & 0.0201 & 0.171 \\
\hline 990042 & TNT/C-SS-2 & 5.0092 & 0.0145 & 51.5791 & 51.6044 & 0.0108 & 0.216 \\
\hline 990043 & TNT/C-SS-3 & 5.1050 & 0.0155 & 51.8081 & 51.8349 & 0.0113 & 0.221 \\
\hline 990044 & TNT/C-SS-4 & 5.1489 & 0.0157 & 51.5527 & 51.5750 & 0.0066 & 0.128 \\
\hline 990045 & TNT/C-SS-6 & 5.0625 & 0.0156 & 51.6660 & 51.6894 & 0.0078 & 0.154 \\
\hline 990046 & TNT/C-SS-7 & 5.1886 & 0.0152 & 51.5693 & 51.5970 & 0.0125 & 0.241 \\
\hline 990047 & TNT/C-SS-8 & 5.1343 & 0.0151 & 51.1326 & 51.1559 & 0.0082 & 0.160 \\
\hline 990048 & TNT/C-SS-9 & 5.2677 & 0.0152 & 51.4417 & 51.4750 & 0.0181 & 0.344 \\
\hline 990049 & TNT/C-SS-10 & 5.0708 & 0.0150 & 51.7438 & 51.7651 & 0.0063 & 0.124 \\
\hline 990050 & TNT/C-SS-11 & 5.1727 & 0.0146 & 51.8871 & 51.9024 & 0.0007 & 0.014 \\
\hline 990051 & TNT/C-SS-1 & 5.0228 & 0.0143 & 51.6121 & 51.6370 & 0.0106 & 0.211 \\
\hline 990052 & TNT/C-GSS-1 & 5.0390 & 0.0154 & 51.7175 & 51.7350 & 0.0021 & 0.042 \\
\hline 990053 & TNT/C-ST-1 & 5.3039 & 0.0155 & 51.8583 & 51.8753 & 0.0015 & 0.028 \\
\hline
\end{tabular}

